\title{
ARTE ROMÁNICO Y EPIGRAFÍA ROMANCE. LAS PRIMERAS IMÁGENES DE LA LENGUA VULGAR EN ITALIA, FRANCIA Y ESPA NA
}

\author{
Daniel Rico CAMPS \\ Universidad Autónoma de Barcelona
}

La reciente publicación por Livio Petrucci del primer corpus preceptivo de la más antigua epigrafía en lengua romance, confirma la impresión que ya se podía tener ojeando las entradas epigráficas del Inventaire systématique des premiers documents des langues romanes, de Barbara Frank y Jörg Hartmann $^{1}$, o los testimonios aducidos por Maria Luisa Meneghetti en su conocido ensayo sobre los primeros pasos de la literatura romance ${ }^{2}$. A saber: que en la Europa románica el debut de la epigrafía vulgar se produjo en un marco figurativo ${ }^{3}$. Si hacemos caso omiso del antiguo y excepcional Graffito liturgico del siglo IX en la Catacumba de Commodilla [1], que en rigor no es una inscripción sino, justamente, un grafito -fruto por consiguiente de un pronto individual que no puede equipararse al oficio y planificación que rigen la concepción y ejecución de una inscripción en sentido estricto-, de las once inscripciones o, mejor dicho, unidades epigráficas fechables en los siglos XI y XII [2-12], sólo hay dos -el epitafio del juez Giratto [9] y la firma del arquitecto Juan de la Casa en Castillon-en-Couserans [12]- que no pertenecen a la tipología de las «didascalie»o «iscrizioni -en la definición del autor- progettate per riferirsi a un'immagine» (p. 43). Esta acusada desproporción entre textos autónomos y textos vinculados a imágenes sería incluso más extrema si a las once inscripciones mencionadas les sumásemos otras cinco datadas normalmente en la misma época y que Petrucci ha excluido del corpus (sin renunciar

\footnotetext{
${ }^{1}$ Tübingen, Gunter Narr Verlag, 1997, II, pp. 9-37.

${ }^{2}$ Le origini delle letterature medievali romanze, Roma-Bari, Laterza, 1997.

${ }^{3}$ L. Petrucci, Alle origini dell'epigrafia volgare. Iscrizioni italiane e romanze fino al 1275, Pisa, Edizioni Plus \& Pisa University Press, 2010. En adelante, las referencias al libro de Petrucci se incluirán en el cuerpo del texto, indicando entre paréntesis el número de página (p.) y entre corchetes los lemas [cifras o letras] de las inscripciones y sus respectivas fichas e ilustraciones. En general, copiaré todas las inscripciones con las abreviaturas resueltas y con la acentuación y puntuación modernas.
} 
no obstante a editarlas) por razones diversas y en general convincentes [A-E], y es que cuatro de esas cinco son también 'didascálicas'. En realidad, el desequilibrio se acentúa en cuanto añadimos a la colección el escaso número de unidades epigráficas que parecen haber escapado a la meticulosa indagación del profesor italiano y que, por lo que conozco, se reduce a dos: el grotesco, pero inestimable conjunto de letreros que enriquecen la iconografía 'vulgar' del alero occidental de la iglesia de San Quirce de Burgos, sobre el que trataré con cierto detalle más adelante [figs. 3-4], y la graciosa inscripción FOL DIVES, «dont le premier mot s'apparente à la langue vernaculaire, le second étant en latin», grabada en el cimacio de un capitel de la iglesia de NotreDame d'Orcival con la representación del castigo del avaro [fig. 5] .

En resumen: once de las trece inscripciones o series epigráficas en lengua romance que nos han llegado de los siglos XI y XII fueron concebidas y realizadas en estrecha articulación con motivos o programas iconográficos. La relación es evidente y se hace incluso más notoria cuando se compara con el balance que nos ofrece el siguiente periodo de la epigrafía vulgar, el siglo XIII, en que la inscripción 'didascálica' sufrió un extraordinario «crollo quantitativo e funzionale» (p. 47) frente al decidido avance de la lengua vulgar en el ámbito del epitafio, que en cambio había sido excepcional en la etapa anterior. De las treinta unidades romances localizadas por Petrucci entre 1200 y 1275 (fecha límite del corpus), sólo cuatro están asociadas a imágenes (la abrumadora mayoría de las restantes son funerarias) ${ }^{5}$. Más aún, de estas cuatro, todas menos el conjunto de la Sainte-Chapelle parisina [22] son conmemoraciones laicas de una donación o fundación piadosa -en Sainte-Vaubourg, Valencia y Rouen [36, 41, 42]-, lo que las aleja por partida doble del modelo dominante en las inscripciones del periodo anterior, surgidas «piuttosto dall'esigenza di promuovere la pietà che di manifestarla, cioè da un'esigenza piuttosto clericale che laica» (p. 45), y las hace más próximas, en el fondo, a la epigrafía funeraria que a la que podríamos llamar 'epigrafía

${ }^{4}$ Corpus des inscriptions de la France médiévale (en adelante, CIFM), 18, Paris, C.E.S.C.M., 1995, núm. 77, p. 231.

${ }^{5}$ «Sono esclusi, comm'è ovvio, gli epitaffi accompagnati dall'immagine del defunto, perché l'epitaffio si riferisce, salvo rarissime eccezioni, al morto e non alla sua immagine» (p. 43, n. 13). Entre las pocas inscripciones hispanas dentro de dicho arco cronológico que podrían añadirse a la antología de Petrucci, destaca un conjunto catalán apenas conocido, fechable a principios del siglo XIII (si no a finales del XII) y que todavía no ha sido editado como es debido: tres inscripciones del tipo A. SARTRE ME FEU P(icar) -o quizá F(er)- grabadas en los ábacos de sendos capiteles con decoración vegetal, zoomorfa o arquitectónica del interior de la iglesia de Santa María de Agramunt, en las que la historiografía tiende a leer las firmas de los picapedreros mejor que los nombres de los oferentes o costeadores de las labras (cf. J. M. Planes i Cosa, Santa Maria d'Agramunt i les seves portalades: aproximació històrico-artística, Agramunt, Ajuntament d'Agramunt, 1985, p. 31, y R. Bernaus i Santacreu, en Catalunya Romànica, XXIV, Barcelona, Enciclopèdia Catalana, 1997, pp. 511 y 513). 
pastoral', por cuanto comparten con el género epitáfico tanto la dimensión conmemorativa como la orientación, en última instancia, escatológica (pro remedio animae).

De toda esta amalgama de datos (reforzada ahora por el puñado de ejemplos que he podido aportar), extrae el profesor Petrucci dos conclusiones principales. Por un lado, como ya sabemos, que en el periodo de los orígenes «l'aggancio dell'iscrizione alle immagine» fue, en efecto, «un movente specifico all'impiego del volgare» en su vertiente epigráfica o monumental, razón de peso -me permito añadir- para que la historia del arte tenga algo que decir sobre el asunto. Por otro, la constatación de que «la prima promozione epigrafica del volgare alligna laddove si manifestano esigenze "di punta" [es decir, las presumibles en iglesias «non proprio secondarie»y en manufacturas "di notevole quando non eccezionale rilievo storico-artistico"], che certamente in qualche modo rimandano agli spiriti e alle iniziative di rinnovamento che caratterizzarono la Chiesa del tempo [...], a punte di sperimentalismo pastorale prodottesi nel clima riformatore della Chiesa del XII secolo» (pp. 45-47). Todo ello confirma una vez más la tesis de Michel Banniard según la cual el acceso a la escritura de las lenguas vulgares dependió tanto de la conciencia lingüística de sus hablantes como de poderosas decisiones extralingüísticas ${ }^{6}$.

No puedo sino compartir estas apreciaciones en sustancia, a condición no obstante de que no se sobrevalore el papel que las inscripciones vulgares de los siglos XI y XII pudieron desempeñar en el despegue epigráfico del Doscientos. El profesor Petrucci ciertamente no lo hace, pero tampoco llega a recalcar este punto como es necesario si queremos entender en su justa medida el carácter y alcance de la «prima promozione epigrafica del volgare». Es razonable pensar que la más antigua epigrafía romance contribuyó de algún modo a abrir el campo de la escritura a la lengua vulgar, pero todo apunta a que lo hizo de una forma extremadamente limitada y, a menudo, paradójica. Limitada porque trece testimonios romances, frente a los centenares de inscripciones en lengua latina conservados del mismo periodo, constituyen en verdad un grupo demasiado reducido para suponerle ningún efecto emulador de cierta envergadura, máxime cuando la experiencia eminentemente 'didascálica' de época románica -en el sentido histórico-artístico de la palabra- apenas tuvo repercusión en la fase siguiente, ya gótica, como pone claramente de manifiesto el propio «crollo quantitativo e funzionale» mencionado anteriormente, el cual viene a demostrar que lo que el siglo XIII asimiló de la experiencia vulgar de la

\footnotetext{
${ }^{6}$ Viva voce. Communication écrite et communication orale $d u I^{e}$ au IX $X^{e}$ siècles en Occident latin, $\mathrm{Pa}-$ ris, Institut des Études Augustiniennes, 1992, p. 47, citado por el propio Petrucci, ob. cit., pp. 23-24 y 45. 
etapa anterior fue de todas todas la excepción: la manifestación, desligada de la imagen, de un impulso piadoso individual. Es evidente que trece casos son bastantes más que los escasos tres (todos franceses) contabilizados por Robert Favreau en su excelente manual de epigrafía medieval, pero a mí me siguen pareciendo muy exiguos y «trop isolés pour pouvoir être considerés comme un veritable point de départ» ${ }^{7}$. Digamos pues, por mor de precisión, que la primera promoción epigráfica de las lenguas romances fue, en realidad, un tímido y frustrado despertar, una iniciativa creativa y original pero, a la postre, truncada o profundamente replanteada, sospecho que por estar estrechamente sujeta a un «sperimentalismo pastorale»-expresión acertada donde las hayaque fue un rasgo tan distintivo de la Iglesia de los siglos XI y XII como caduco para la de la centuria siguiente.

Promoción limitada, decía en el párrafo anterior, y en buena medida paradójica, pues es verdad que el estreno epigráfico de las lenguas romances no significaba la «generica promozione del volgare a una forma di scrittura qualsiasi ma alla dignità epigrafica, "il grado più alto di espressione scrita" in ogni società alfabetizzata ${ }^{8}$, pero también que dicho estreno se produjo -por decirlo así- ex contrario en una porción nada desdeñable de casos: unas veces concibiendo el vulgar como lengua culturalmente inferior al latín con la que sólo era factible expresar las veleidades o debilidades del ser humano; y otras, rebajándola a una jerga de la peor calaña en aras a demostrar la bajeza moral y social de sus hablantes. No hay mejor forma de cerciorarse de lo que digo que repasando uno a uno los trece testimonios conservados. La perspectiva que nos interesa adoptar es la de la imagen (voluntaria o involuntaria) de la lengua que cada uno de ellos revela. Si no me equivoco, el nuevo enfoque consiente reagrupar los trece casos (o por lo menos los de interpretación inequívoca) en tres clases de textos que se corresponden con los tres grados de valoración que el romance ocupó en la representación jerárquica que la Iglesia se hizo de la lengua en general.

En el nivel más alto tenemos las inscripciones que hicieron un uso positivo (o más bien neutro, pero a la larga dignificante) de la lengua hablada, por cuanto parecen esquivar intencionadamente el señorío latino de la epigrafía coetánea con el propósito de acercar ciertas figuras o historias sagradas al lenguaje (y espíritu) del común de los mortales. Es lo que ocurre, sin asomo de dudas, en el bien visible S. CLEMENTE que identifica al santo titular en

\footnotetext{
${ }^{7}$ Épigraphie Médiévale, Turnhout, Brepols, 1997, pp. 104-105.

${ }^{8}$ Petrucci, ob. cit., p. 45, citando a su vez a A. Petrucci, «Il volgare esposto: problemi e prospettive», en C. Ciociola (ed.), «Visibile parlare». Le scritture esposte nei volgari italiani dal Medioevo al Rinascimento, Napoli, Edizioni Scientifiche Italiane, 1997, p. 46.
} 
el fresco conocido como Guidizio patriculare de la basílica inferior de San Clemente de Roma [2], y en el céntrico S. LADRE cincelado al pie de la estatua de San Lázaro que presidía la portada principal de la iglesia homónima de Avallon [8]. Ambos epígrafes son un claro reflejo de «la ricerca [por parte de sus respectivos responsables eclesiásticos] d'una comunicazione più aperta ai fedeli», «d'un'apertura pastorale sulla vita quotidiana dei fedeli» (p. 43) con el objeto, no de hacerse entender (como se dice a menudo olvidando que los analfabetos no saben leer ni en latín ni en romance), sino de familiarizar el nombre del santo y avecindarlo de alguna forma en Avallon. Escribir Ladre en vez de Lazarum equivalía a sentir su nombre como «le mot du terroir» y a hacer del Lázaro del santoral universal un lugareño -si me permite Peter Brown- «muy especial». Al tiempo, implicaba reconocer en la lengua romance una eficacia comunicativa que no debió ser muy diferente de la que experimentaron infinidad de literati que se sintieron incapaces de renunciar a la lengua materna cada vez que tenían que expresar realidades demasiado palpables o actuales para un latín ya trasnochado o excesivamente abstracto: «addidit et VI tormenta, que vulgo perrerie vocantur...»».

En este mismo grupo deberíamos incluir las dos -no cuatro, corrige Petrucci- inscripciones romances que conviven con cuarenta latinas en la célebre puerta de bronce de la catedral de Monreale (CAIM UCISE FRATE SUO ABEL, en el panel con dicho tema, y LA QUARENTINA, como titulus de las Tentaciones de Cristo en el desierto) [10], y quizá también el -hasta Petrucci- inédito LEONE que, en relación de pendant con un ángel, flanquea la cruz con alfa y omega y las enigmáticas letras R(ex?) y S(alvator?) en un relieve de la iglesia de los Santos Pedro y Leonardo de Poggibonsi, acaso del siglo XI [4]. La diferencia respecto a los ejemplos de Roma y Avallon es que en éstos no hay manera de entrever siquiera la función a la que el romance atiende. En los dos letreros de Monreale no tiene la pinta de guardar, en efecto, ninguna relación con los temas que designa, indicio en principio suficiente para «credere che la loro presenza sia in definitiva casuale» y no obedezca en absoluto «a una meditata esigenza comunicativa» (p. 45) ${ }^{10}$. Mayor es el misterio que rodea al solitario LEONE de Poggibonsi, desde el momento en que, por no saber, ni siquiera sabemos si se trata de un león negativo, con «valenza diabolica»-como defiende Petrucci al verlo situado «sul lato dei dannati e

\footnotetext{
${ }^{9}$ M. Hélin, «Vulgarismes et néologismes dans la latinité médiévale», Le Moyen Âge, 69 (1963), pp. $247-258$ (p. 251).

${ }^{10} \mathrm{~A}$ lo mismo apunta la cronología tardía de la puerta (datada en 1185) y su realización en Pisa, ciudad donde «il volgare aveva ormai raggiunto [...] una certa, per così dire, "maturità epigrafica"» (p. 45), como vendría a demostrar el epitafio bilingüe de Giratto [9], fechado entre 1174 y 1176.
} 
separato mediante una cornice della croce» (p. 83)-, o de un león positivo, sea como figura de Cristo «leo fortis» -a la manera del que ocupa su mismo lugar, junto al Crismón, en el famoso tímpano de Jaca (aunque con otro león y no un ángel en el lado opuesto)-, sea como fuerza protectora, junto al ángel y la cruz, de la puerta a la que el relieve debió estar destinado ${ }^{11}$.

Es posible que en las inscripciones de Poggibonsi y Monreale el romance se introdujese por acto reflejo, en contraste con la modalidad reflexiva que adivinamos en Roma y Avallon, pero los cuatro ejemplos coinciden en esencia por el mero hecho de abrirse a la lengua materna de una forma propicia o benévola y, sin embargo, neutra, absteniéndose de proyectar sobre ella ningún juicio de valor, ni el positivo que revela, pongamos por caso, el Cantar de Almería al encomiar la lengua de los «Castellae vires» por sus resonancias «quasi tympanotriba» (v. 145), ni el negativo que propagaron a los cuatro vientos infinidad de clérigos. Ninguno de estos extremos ocurre en nuestras cuatro inscripciones, donde el vulgar se usa por razones de orden puramente instrumental o utilitario, como en Roma y Avallon, o de forma, por decirlo de algún modo, natural o inconsciente, como en Monreale y Poggibonsi. Quiere esto decir que nuestro primer grupo epigráfico no nos ofrece, en realidad, ninguna imagen de la lengua romance, ni favorable ni desfavorable, a pesar de ocupar el grado más alto en la escala de valores de la primera epigrafía vulgar.

El segundo grupo se sitúa ya en un terreno menos neutral. Lo componen aquellas inscripciones que se fijaron en las posibilidades simbólicas y expresivas de la lengua romance y que además las supieron aprovechar prescindiendo de su utilidad pastoral. No es pues un disparate suponer que sus autores quisieron rendir con ellas un cierto homenaje a la lengua oral, en la que descubrieron una particular modulación formal y quizá también un registro moral cabalmente evangélico: el sermo humilis. Pero ahí se hallaba también su propio límite: la lengua materna accedía ahora a un estatus artístico, pero no lo hacía motu proprio, por su propia autonomía y dignidad, sino por expreso contraste con un latín cultural y espiritualmente superior. Enfrentada a la lingua sacra, la lingua mundi adquiría una función expresiva y significante, pero a costa de caer del frío peldaño donde la habíamos visto antes y quedar atrapada en un registro plebeyo que sólo se consideraría apropiado para expresar las emociones y actitudes más mundanales o terrenales del ser humano; en el mejor de los casos, sus miedos y miserias más comprensibles, menos condenables. Mundanal es, en el fondo, la autosatisfacción (en ningún

\footnotetext{
${ }^{11}$ Combinación apotropaica de motivos a la que no es difícil encontrarle precedentes y paralelos: véase, por ejemplo, A. Grabar, «Deux portails sculptés paléochrétiens d'Égypte et d'Asie Mineure et les portails romans», Cahiers Archéologiques, 20 (1970), pp. 15-28, espec. p. 28.
} 
caso voluntad de fama) que llevó a IOAN DE LA CASA a dejar constancia escrita de que FO MAESTRE DE LA OBRA de San Pedro en Castillon-enCouserans [12], grabándola al pie (eso sí, con la piadosa humildad que cabía esperar en el buen cristiano) del libro que ostenta la imagen de PETRUS PRINCEPS REGNI CELORUM esculpida por el propio maestro en la fachada de la iglesia. Y terrenales son, en el fondo, los destinatarios y la angustia que trasluce el aviso para navegantes que cierra la caja funeraria del juez Giratto [9]: HOME KE VAI PER VIA PREGA DEO DELL'ANIMA MIA SÌ COME TU SÈ EGO FUI SICUT EGO SUM TU DEI ESSERE. No en balde, el texto se halla en el borde inferior del sarcófago, visiblemente desmarcado de la inscripción latina que recorre la cornisa superior: BIDUINUS MAISTER FECIT HANC TUMBAM AD DOMINUM GIRATUM ${ }^{12}$.

Las dos inscripciones (tal vez la primera más que la segunda) son un ejemplo precioso del provecho simbólico que podía extraerse de la «opposition tonale, dans la perspective de la fameuse "roue de Virgile"», entre el latín dominante y el vulgar emergente ${ }^{13}$. A diferencia del romance pasivo de los rótulos de Roma o Avallon, ahora descubrimos (también con la vista) un romance activo, lingüística, social y moralmente significativo, pero que nos ofrece una imagen desfavorable de sí mismo en tanto que depende exclusivamente de la posición subalterna que ocupa respecto al venerable y dominante latín. Es importante observar que la oposición no se reduce a la lengua, sino que se pone también de manifiesto mediante la ubicación contrastada del texto, tanto en la tumba pisana como en la escultura occitana: el celestial latín arriba, el terrenal romance abajo.

Una tercera pieza que a mi juicio encaja bien en este grupo de inscripciones, a las que cabría calificar de 'expresivas sin función pastoral', se halla en una de las dos placas conservadas del antiguo retablo mayor de la abadía de Grandmont [11]. La obra, amable y delicada, es conocida de todos [fig. 1]: el fundador de la orden, San Esteban de Muret, con nimbo, tonsura y libro pegado al corazón, escucha atentamente (con una mirada tan receptiva como la palma -bien abierta- de su mano izquierda) las palabras que le dirige su discípulo predilecto, Hugo de Lacerta, retratado con las espesas barbas de los conversos y apoyado en un bastón. Bajo el arco que enmarca y ennoblece la escena, circula el siguiente texto: N'IGO LASERT PARLA AM N'ETEVE DE MURET $^{14}$. La leyenda se despliega y organiza de la forma más perfecta

\footnotetext{
${ }^{12}$ Donde «la stravaganza d'identificare il defunto attraverso la firma dell'artefice, inconcepibile in un autentico epitaffio, risulta assai più comprensibile tenendo presente che le iscrizioni pisane su sarcofagi erano piuttosto "intitolazioni" del manufato che veri e propri epitaffi» (p. 95).

${ }^{13} \mathrm{P}$. Zumthor, Langue et techniques poétiques a l'époque romane (XI ${ }^{-}$-XIII siècles), Paris, Klincksieck, 1963 , p. 84.

${ }^{14}$ La lectura correcta se debe a F. François-Souchal, «Les émaux de Grandmont au XII ${ }^{\mathrm{e}}$ siècle», 


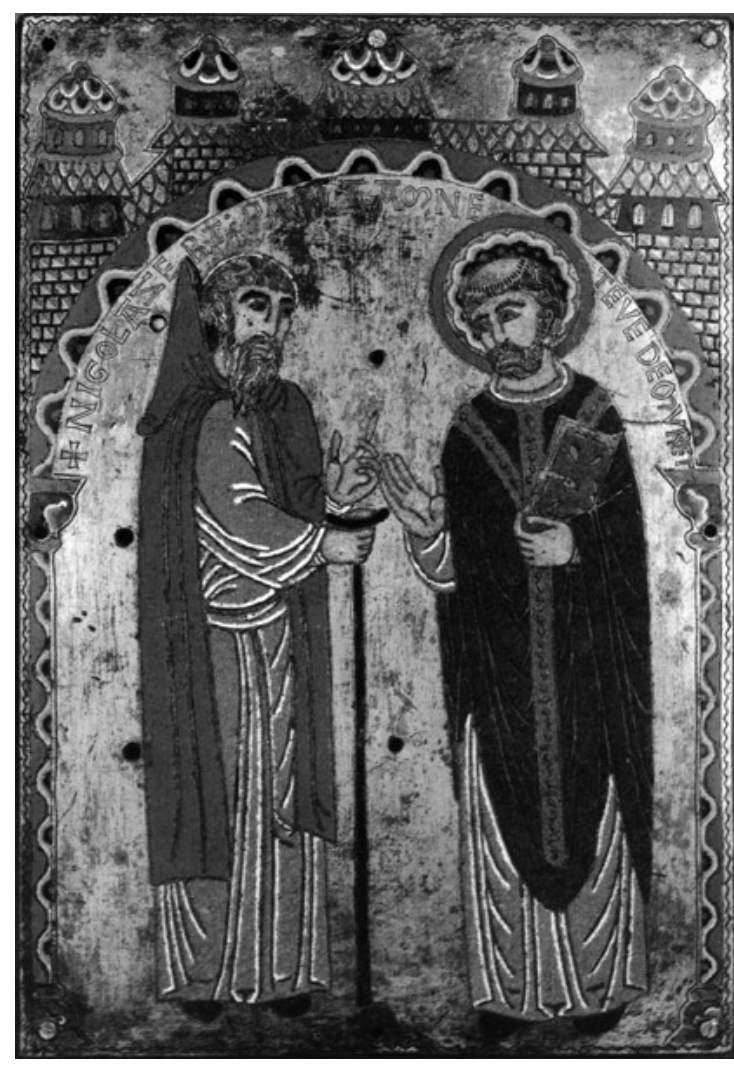

Fig. 1: Saint-Sylvestre (Haute-Vienne), abadía de Grandmont, placa del retablo del altar mayor (Musée de Cluny, Paris). Imagen de dominio público. que pueda imaginarse. No es sólo que su recorrido de izquierda a derecha acompañe suaveamente las palabras que Esteban dirige a Hugo, sino que lo hace al ritmo pausado de una ordinatio en la que cada sintagma se sitúa en el campo exacto de lo que le corresponde designar: los dos sustantivos abrazan el perfil de sendos protagonistas e incluso se cruzan suavemente con su atributos más distintivos (la capucha y el nimbo respectivamente), mientras que la forma PARLA AM cae exactamente sobre el espacio vacío que se abre entre ambos personajes con la visible intención de llenarlo de la 'parla' imaginada. La didascalia es descriptiva, sin duda, pero casi se siente elocutiva: al acompañar, literalmente, la

mirada de Hugo hacia la de su maestro y expresarse en el sermo maternus de los conversos, la inscripción vendría a hacerse eco de la propia voz del discípulo. Que aquí tan sólo tengamos un texto romance no debiera llamarnos a engaño. En realidad, su autonomía es más aparente que real. A pesar de que la otra placa conservada en el Museo de Cluny (con la Adoración de los Reyes Magos) es anepígrafa, no es justo olvidar que el retablo de Grandmont estaba en origen decorado con otras escenas (de la Pasión y de la propia vida de San Esteban) en las que no es descabellado imaginar un elevado número de inscripciones en latín ${ }^{15}$. Diré más: en el marco en el que se hallaba el retablo, ni más ni menos que el altar mayor, el latín estaba omnipresente, si no

Bulletin Monumental, 120 (1962), pp. 339-357 (345-357), donde se ensaya además un excelente análisis iconográfico de la pieza.

${ }^{15}$ Cf. J.-R. Gaborit, «L'autel majeur de Grandmont», Cahiers de Civilisation Médiévale, 19 (1976), pp. 231-246 (pp. 235-236). 
en términos físicos, al menos en la expectativa (visiva, auditiva y, sobre todo, espiritual) de quienes allí tenían acceso, lo que significa que el rótulo occitano de la obra contrastaba con la integridad toda, por decirlo así, del contexto en el que estaba inscrita y debió de sobresalir -o 'parlar'- con más fuerza si cabe que la firma del maestro De la Casa en Castillon-en-Couserans.

Se sospecha, con razones de peso, que la placa de Grandmont reflejaría en cierto sentido la política de reconciliación entre clérigos y conversos impulsada por el séptimo prior de la orden, Gerardo Itier, tras los violentos enfrentamientos que se habían desencadenado durante la prelatura de su predecesor Guillermo de Treignac ${ }^{16}$. El dato sugiere a Petrucci que el romance de la inscripción «corrisponderebbe dunque a una forma d'apertura non già pastorale, dei chierici verso i fedeli, ma gerarchica, dei frati chierici verso i frati conversi, ai quali l'accosatmento all'altare sarà stato certo possibile» (p. 46). Es posible. Se me ocurre, abundando en esta idea, que el romance se pudo concebir como un guiño (simpático o estratégico) de los clérigos hacia los conversos, con la precisa función de ganarlos para su causa o de aparentar o confesar lo contrario (una renuncia a su favor). Pero también me pregunto si, a estas alturas del siglo XII (el retablo se fecha hacia 1189-1190), no estaremos cometiendo un pequeño error al buscarle a la epigrafía romance (y lo mismo valdría para la puerta de Monreale, ut supra, n. 10) una justificación excesivamente anclada en una perspectiva comunicativa o funcional. Quiero decir que no hay que descartar la posibilidad de que, en Grandmont, la lengua materna se concibiese sencilla y rasamente como un recurso expresivo en la línea de las inscripciones también tardías de Giratto y Juan de la Casa, en este caso como un medio suplementario para caracterizar con mayor viveza o realismo la laicidad del monje barbudo y la humana y cariñosa apertura, no ya de los clérigos de Gerardo Itier hacia los conversos, sino del propio Esteban de Muret hacia su más querido discípulo. La reciente pacificación del convento podría haber determinado la elección de la escena, venerable recuerdo de una fraternidad ejemplar, pero no necesariamente la utilización del romance, que en aquellas fechas estaba suficientemente proviso de validez estilística como para desatender su originaria función comunicativa.

Nada más alejado en este sentido del tercer grupo de inscripciones, que en ningún caso supera el mediodía del siglo XII, a pesar de estar constituido por el mayor número de unidades epigráficas (hasta seis, si incluimos los testimonios de Burgos y Orcival evocados al inicio de estas páginas), y que no sólo coincide estrictamente -en el tiempo y en el espacio- con el gran

\footnotetext{
${ }^{16}$ Gaborit, art. cit., p. 235, reconoce incluso un eco de dicha política en «le fait que l'inscription soit en langue vulgar, donc compréhensible même pour les convers illiterati».
} 
Daniel Rico CAMPS

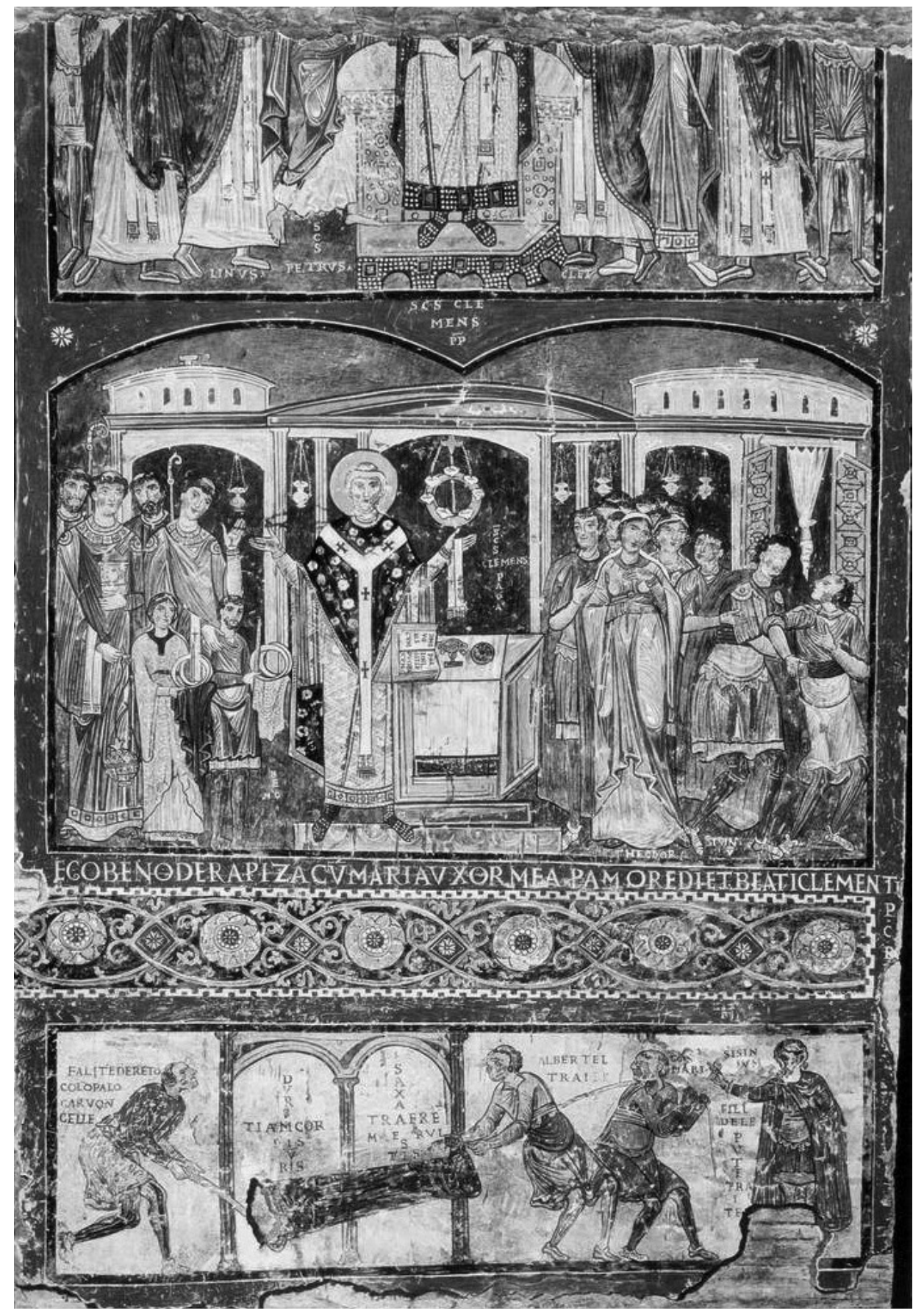

Fig. 2: Roma, basílica inferior de San Clemente, pintura mural según la acuarela de Wilpert, ob. cit. (n. 17), fig. 40. 
despliegue figurativo del románico pleno, sino que participa plenamente, según veremos, de su 'experimentalismo' comunicativo. Al igual que el grupo anterior, también éste se caracteriza por hacer un uso simbólico y colorista de la lengua vulgar, pero dirigido esta vez a satisfacer una concreta intención pastoral, a la manera de las inscripciones de Roma y Avallon, aunque en una dirección bien diferente. Ahora lo uno va con lo otro, lo expresivo con lo pastoral, y la promoción de la lengua alcanza el cénit de la paradoja, por lo menos en una mayoría de casos en que del vulgar tan sólo se aprovechó el registro más tonto, ruin o indecoroso con el firme propósito de reforzar una lección moral en la que la lengua salía tan malparada como el pecado o costumbre objeto de la reprobación. Precisamente, un rasgo definitorio del conjunto es la comicidad que las formas romances revisten en todas (o casi todas) las unidades epigráficas. Comicidad que, al estar inscrita en programas iconográficos de tenor edificante o ejemplar, tuvo que asumir como propia la función hiriente y moralista de la sátira: la ridiculización de alguien o de algo mediante la recreación mordaz de su lengua o universo expresivo.

El caso más conocido nos lleva de nuevo a la basílica inferior de San Clemente de Roma, en esta ocasión frente al fresco mandado realizar entre 1078 y 1084 por un tal Beno de Rapiza y su mujer Maria Marcellaria [3]. De los tres registros en que está organizada la pintura, con la Entronización y la Misa del santo titular arriba y en medio respectivamente, nos interesa el cuadro inferior, que narra el intento fallido de arrestar a Clemente por parte del patricio Sisinio, convencido de que el santo (a su juicio, un mago) ha hechizado a su mujer, convertida al cristianismo, con la intención de seducirla [fig. 2 $]^{17}$. Obedeciendo las órdenes de su pagano patrón, togado y con gesto de mando a la derecha de la escena, tres siervos tratan con inútil esfuerzo de arrastrar una pesada columna en la que todos creen reconocer al papa, que con tan milagroso ardid consigue eludir la captura. La vozy presencia del santo ausente se hace visible en las dos leyendas que se yerguen triunfales sobre la columna, en solemne disposición cruciforme, bajo el cobijo de nobles arcos y en el litúrgico latín de la Passio sancti Clementis: DURITIAM CORDIS VESTRIS / SAXA TRAERE MERUISTIS, dice la santa reprimenda dirigida contra SISINIUM, en franco contraste con los violentos alaridos que el pagano prorrumpe en un bruto y vulgar italiano: FILI DE LE PUTE, TRÀITE / GOSMARI, ALBERTEL, TRÀITE / FÀLITE DERETO CO LO PALO, CARVONCELLE.

\footnotetext{
${ }^{17}$ El lamentable deterioro del mural tras las excavaciones de los sesenta nos obliga a basar el análisis en reproducciones antiguas, la más fiable de las cuales es la acuarela del padre Joseph Wilpert, Die römischen Mosaiken und Malerein der kirchlichen Bauten von IV. bis XIII. Jahrhundert, Freiburg, Herdersche Verlagshandlung, 1917, fig. 240.
} 
La identificación de la triple soflama romance con la voz del patricio y su lectura de derecha a izquierda es la interpretación que ha tenido mayor acogida en una filología que ha llegado a proponer cerca de veinte lectiones ligeramente diferentes aduciendo variantes relativas al texto, su orden de lectura, la función denominativa o elocutiva de los nombres de los protagonistas y su hipotética participación en la acción oral ${ }^{18}$. Lo que más ha despistado a lectores y editores es la atropellada dispositio de la inscripción, que parece circular sin ton ni son, ajena a la más elemental de las reglas gramaticales, cuando en realidad semejante barullo es un acerado efecto artístico que tiene como principal objetivo cargar la atmósfera de griterío y confusión y expresar visualmente la naturaleza barbullante del habla de Sisinio (y sus verdugos). Basta con percatarse de la densa e inspirada correlación entre figuras e inscripciones: el movimiento desordenado y sin-sentido del texto romance se corresponde plenamente con las palabras desapuestas y desesperadas que lo recorren al tiempo que con la embrollada actividad de los esclavos, cuyo modo inestable, nervioso, entrecruzado, asimétrico - «descoordinado», lo llamaría Meyer Schapiro ${ }^{19}$ - contrasta con el equilibrio tectónico de la asamblea eucarística pintada justo encima y de la propia arquería que encuadra y dignifica el milagro y la voz del santo. Una voz, por cierto, cuyo doble alarde cruciforme se hace literalmente eco de la postura orante de San Clemente y del curso -también en cruz- de la rúbrica que lo acompaña, de la misma forma que el vaivén de todo lo que cae fuera de la doble arcuación tiene su inicio en el extremo derecho del cuadro intermedio, donde la evocación de la milagrosa sordera y ceguera del prócer pagano introduce la única nota de discordancia formal - con figuras zigzagueantes y centrífugas- en una Misa de estructura rigurosamente hierática y centrípeta.

Este desorden expresivo y simbólico de la inscripción ha permitido, por otro lado, desperdigar a capricho los tres nombres de los verdugos (Gosmari, Albertel, Carvoncelle) con la evidente intención de que los tres adquieran una clara función designativa (clara por su inmediata proximidad a las figuras que identifican) al margen de su condición sintagmática (un poco como en Grandmont, pero a lo loco). Por eso me parece tan legítimo -o tan plausible desde la perspectiva histórica- atribuir la entera cantinela romance a Sisinio, como repartirla entre él y sus subordinados sin que se pierda por ello la naturaleza

\footnotetext{
${ }^{18}$ Las recoge todas hasta la fecha S. Raffaelli, «Sull'iscrizione di San Clemente. Un consuntivo con integrazioni», en F. Sabatini, S. Raffaelli y P. D'Achille, Il volgare nelle chiese di Roma. Messaggi graffiti, dipinti e incisi dal IX al XVI secolo, Roma, Bonacci Editore, 1987, pp. 35-66, espec. 40-44.

${ }^{19}$ «Las esculturas de Souillac» (1939), Estudios sobre el románico, Madrid, Alianza Editorial, 1984, pp. 122-151.
} 
verbalizada de sus respectivos nombres, de acuerdo con la ingeniosa propuesta de Ornella Castellani Pollidori ${ }^{20}$ :

[Albertel, Gosmari]: Fàlite dereto co lo palo Carvoncelle; [Carvoncelle]: Gosmari, Albertel, tràite; [Sisinium]: Fili de le pute, tràite.

Léase así, de izquierda a derecha, o en el sentido inverso, como prefiere Petrucci (p. 82):

[Sisinium]: Fili de le pute, tràite; [Carvoncelle]: Gosmari, Albertel, tràite; [Albertel, Gosmari]: Fàlite dereto co lo palo Carvoncelle.

Porque tiene razón Sergio Raffaelli cuando subraya que el carácter «iconicoverbale» de la inscripción clementina exige una aproximación con criterios «più propri della figurazione che della scritura: quindi non necessariamente con andamento lineari continuo, da sinistra a destra oppure inversalemnte 'all'araba', ma piuttosto secondo lo sviluppo 'narrativo' delle immagini, che ammette anche arresti, spostamenti, ritorni dello sguardo $»^{21}$. Digamos que la «descoordinación» visual de palabras y figuras no sólo posibilita, sino que pide a gritos, nunca mejor dicho, que la lectura se haga en el (des)orden que uno quiera.

Tal como apuntó Angelo Monteverdi, en las pinturas de San Clemente «per la prima volta il volgare italiano vi appare usato con intento artistico», pero lo hace con «quel sapor comico che per noi ha il dialetto» ${ }^{22}$. Esto es, en su eclesiástico estado de lengua socialmente baja y moralmente reprobable ${ }^{23}$. Ahora, absolutamente todo en el romance (su tono vejatorio, su movimiento esquivo, su naturaleza tornadiza) es negativo y contrario a la crucífera dignidad del latín. El contraste es radical e integral, visivo y verbal. Incluso la repetición de la palabra tráite parece estar orientada a que el oído (y el ojo) cultivado la perciba como cómica (al par que dramática) contrahechura del céntrico y enfatizado traere pronunciado por el santo -auténtico «termine-chiave», advierte Petrucci, de su condena moral (p. 44, n. 19) ${ }^{24}-$, de igual modo que la representación de perfil de todos los actores paganos sin

\footnotetext{
${ }^{20}$ «Sull’iscrizione della chiesa romana di S. Clemente», Lingua nostra, 33 (1972), pp. 33-39.

${ }^{21}$ Art. cit., p. 51 (y p. 61).

${ }_{22}^{22}$ «'iscrizione volgare di San Clemente», Studi romanzi, 24 (1934), pp. 5-18 (18), recogido en sus Saggi neolatini, Roma, Edizione di Storia e Letteratura, 1945, pp. 59-74.

${ }^{23} \mathrm{Cf}$. A. Roncaglia, «Le origini», en Storia della Letteratura Italiana, I, Le origini e il Duecento, dir. E. Cecchi y N. Sapegno, Milano, Garzanti, 1965, pp. 3-224 (p. 178).

${ }^{24}$ Vid. asimismo Raffaelli, art. cit., p. 56. 


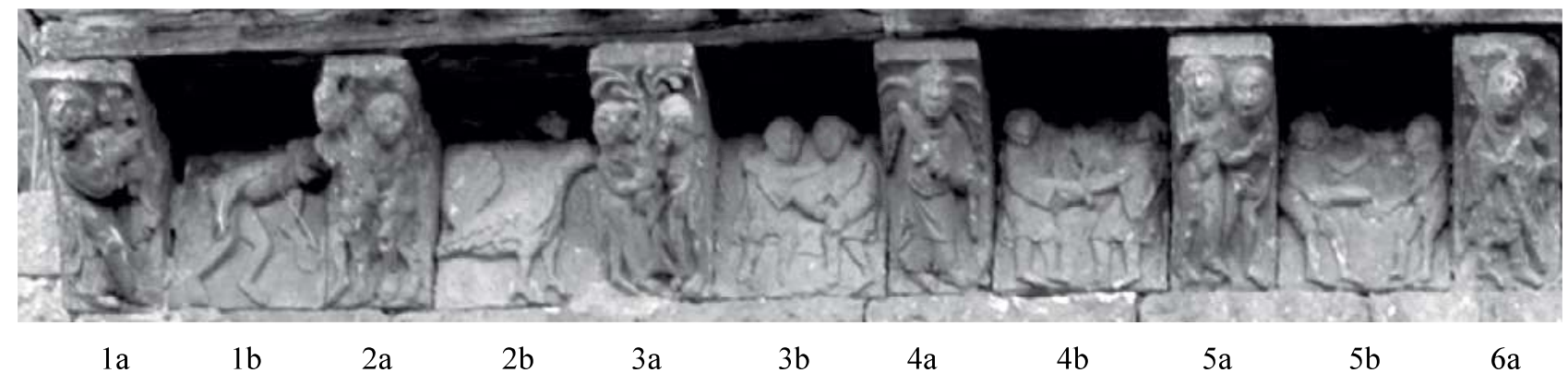

Fig. 3: Relación de imágenes
1a) CREATOR OMNIVM. Dios Creador
1b) MALA CAGO. Hombre defecando
2a) ADAM EVA. Adán y Eva creados a imagen y semejanza de Dios
2b) GALLO. Un gallo
3a) PERCVSSIT PROPRIVM A MORSV EVA MARITVM. Pecado Original
3b) LVCTA. Lucha cuerpo a cuerpo entre dos hombres
4a) ANGELVUS DOMINI. Ángel de la expulsión blandiendo espada
4b) LIDIATORES. Combate a espada entre dos hombres
5a) EIECIT ADAM DE PARADISO. Adán y Eva saliendo del Paraíso
5b) Io. Pareja copulando
6a) FACTVS EST ABEL. Abel con capuchón, cuerno y cayado
6b) PASTOR OVIVM. Cabrito ramoneando en un arbusto
7a) ABEL. Ofrenda de Abel
7b) Rebaño de Abel: tres ovejas y un cordero
8a) KAIN. Ofrenda de Caín
8b) KAIN AGRICOLA. Caín arando con una pareja de bueyes
9a) KAIN IMPIVS. Caín blandiendo el arma del fratricidio
9b) GALLO. Un gallo
10a) ABEL IVSTVS. Abel aterrado tratando de detender el golpe
10b) Io CACO. Hombre defecando
11a) VBI EST ABEL FRATER TVVS. Dios reprendiendo a Caín

excepción (también en el panel de la Misa) y la presumible deformidad de su anatomía (en la acuarela de Wilpert todavía se alcanza a ver el principio de calvicie y la abultada joroba del siervo de la izquierda, así como del lazarillo de Sisinio en el registro intermedio) son la simbólica desviación de la sistemática frontalidad, verticalidad y simetría que ennoblece todas y cada una de las voces, figuras y arquitecturas sagradas del resto de la pintura ${ }^{25}$.

Gian Carlo Alessio ha advertido que la figura de pensamiento que regula el programa de San Clemente es la notatio: «quando per dicta vel facta virtus sive vitium alicuius notatur $\rangle^{26}$. A hombres ignominiosos les corresponde

${ }^{25}$ Recuérdese el capítulo «Frontal and Profile as Symbolic Forms» del extraordinario libro de M. Schapiro, Words and Pictures. On the Literal and the Symbolic in the Illustration of a Text, The Hague-Paris, Mouton, 1973, pp. 27-49, reeditado en Words, Script, and Pictures: Semiotics of Visual Language, New York, George Braziller, 1996, pp. 69-77.

${ }^{26}$ «Tradizione latina e origini romanze», en F. Brioschi y C. Di Girolamo, Manuale di letteratura italiana, 


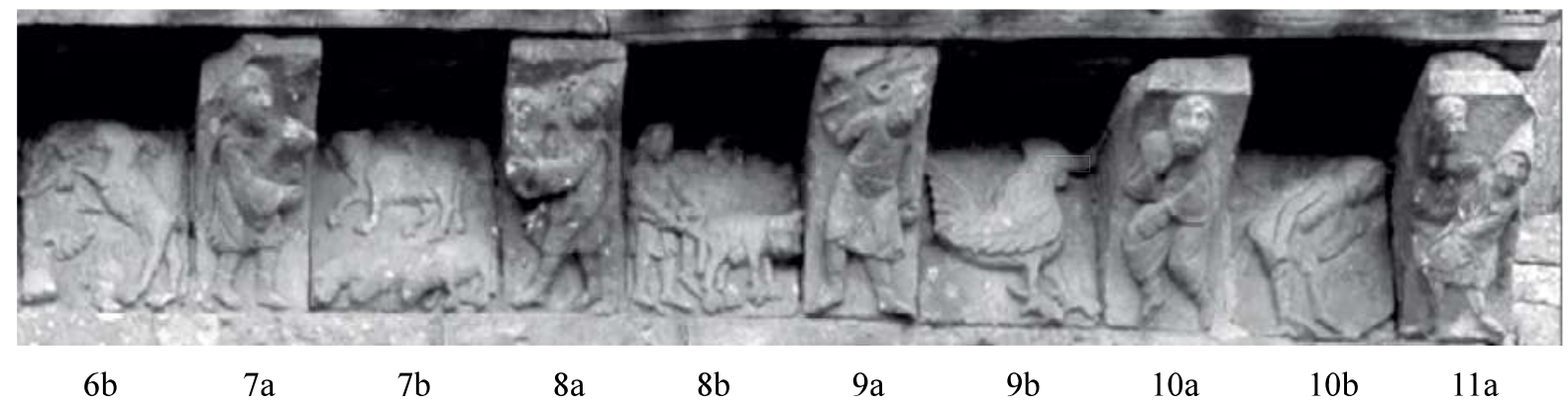

Fig. 3: Los Ausines (Burgos), iglesia de San Quirce, cornisa de la portada occidental (foto: archivo del autor).

hablar «una forma lingüística omogena al loro status sociale e morale. Il prestigio del latino sottolinea l'altezza spirituale del santo; il volgare, avvertito come lingua bassa, ribadisce la bassezza morale del persecutore e dei suoi accoliti $\rangle^{27}$, que el habilidoso artista romano ha sabido reproducir visualmente con el pertinente registro «descoordinado». No es casual que en ocasiones se haya querido buscar la matriz del ciclo clementino en el arte dramático, pues es, en efecto, en el creativo teatro escolar y litúrgico coetáneo donde encontramos algunos de los más sugerentes recursos a la «oposición tonal» de la que hablaba Zumthor. Pienso en esos dramas latinos en que la lengua vulgar aparece de vez en cuando en boca de seres transgresores, desesperados o simplemente profanos, como el Barbarus en el Ludus super Iconia Sancti Nicolai de Hilario de Orléan ${ }^{28}$. Pero también en un texto vernáculo como el Jeu d'Adam, cuya homogeneidad formal se rompe con eficaces quiebros estilísticos en las escenas de mayor violencia, tales las «verbal deceptions and confusions» de Caín en su tenso diálogo con Abel en la inminencia del asesinato ${ }^{29}$, con salidas de tono del tipo «Icist conseil [pagar el diezmo] ne vealt un oeuf!» (v. 665), gráficamente subrayadas además con los pertinentes colores («Cahym sit indutus rubeis vestibus, Abel vero albis»), miradas («respiciet Cahym... quasi subsans») y gestos («Cahym quasi furibundus irruet in Abel») $)^{30}$.

Sin embargo, el programa audiovisual de San Clemente tiene un paralelo mucho más cercano en género y concepto, prácticamente un hermano gemelo, en el alero que corona la puerta occidental de la pequeña iglesia monástica de San Quirce de Los Ausines, en la provincia de Burgos, realizado en fecha próxima a 1147. Lo que allí se cuenta es una verdad tan conocida y universal

I, Dalle origini alle fine del Qattrocento, Torino, Bollati Boringhieri, 1993, pp. 3-44 (pp. 38-40). La definición latina es de Bene de Florencia, Candelabrum, II, 62 (ed. G. C. Alessio, Padova, Antenore, 1983, p. 79).

${ }^{27}$ Alessio, art. cit., p. 40.

${ }^{28}$ Vid. E. Ilvonen, Parodies de thèmes pieux dans la poésie française du Moyen Âge (1914), Genève, Slatkine Reprints, 1975, p. 24, y el texto en K. Young, The Drama of the Medieval Church (1933), Oxford, The Clarendon press, 1962, II, pp. 337-343.

${ }^{29}$ S. Justice, «The Authority of Ritual in the Jeu d'Adam», Speculum, 62:4 (1987), pp. 851-864 (p. 859).

${ }^{30}$ Jeu d'Adam, vv. 4-5, 9 y 11, según la edición de R. Redoli Morales, Le Jeu d'Adam (El drama de Adán). Edición del manuscrito de la Biblioteca Municipal de Tours, Málaga, Servicio de Publicaciones e Intercambio Científico de la Universidad de Málaga, 1994, pp. 46 y 51. 
como la entrada del mal en el mundo a raíz del pecado original [Figs. 3-4]. El espacio disponible es sumamente restringido y la calidad de la escultura mediocre, pero tales pies forzados no impidieron que el artista se las arreglase para desplegar un programa 'epiconográfico' asombrosamente rico en matices y asociaciones ${ }^{31}$. Su mayor logro radica en haber aprovechado con admirable habilidad la ocasión narrativa y simbólica que le ofrecía la alternancia de soportes: mientras los canecillos ilustran un ciclo del Génesis que da cuenta del ascendente bíblico del pecado, las metopas pintan una imagen cruda y ordinaria de su propagación en el mundo y repercusión en la naturaleza humana. Modillones y tabicas (a y b en la numeración de mi fig. 3) se suceden, de izquierda a derecha, en un diálogo e interrelación permanentes, pero también se superponen en bloque y en paralelo como dos mundos diferentes, dotados de autonomía propia, que se corresponden con dos edades de la Historia. El primer plano de los canecillos representa (y no sólo presenta) una realidad sagrada y superior, bíblica, que se expresa en latín, lengua sagrada: Dios CREATOR OMNIUM, abre y cierra (labras la y 11a) este orden primigenio marcado en todo su recorrido por la tragedia de Adán, Eva y Caín, pero en el que también despunta un rayo de esperanza en la figura emblemática y pastoril de Abel precisamente en la pieza más céntrica del alero (6a), en eje con el centro geométrico de la puerta del templo: FACTUS EST ABEL, dice la rúbrica allí inscrita ${ }^{32}$. En los bajos fondos de la cornisa, el segundo plano de las metopas, se desencadena sin freno una realidad carnal e inferior, el mundo miserable e inmundo ( $\mathrm{O}$ munde immunde!», exclamaban muchos con desesperada homofonía) ${ }^{33}$ y su lengua mundana: MALA CAGO (literalmente, 'cago manzanas') y IO CACO ('yo cago') vocifera -y exponeel rústico desvergonzado, tan impulsivo como el GALLO ( 2 b y $9 \mathrm{~b})$, que abre y cierra ( $1 \mathrm{~b}$ y $10 \mathrm{~b}$ ) este reino vulgar y secular herido por la discordia (una LUCTA en 3b, los LIDIATORES de $4 b$ ) y por la bestialidad de unas gentes cuya meta principal, central en la vida no es otra que fornicar y vanagloriarse de ello: IO ('yo'), exclama con descomunal soberbia el mayor contraejemplo que pueda imaginarse del humilde y obediente Abel, justo a su lado (5b).

\footnotetext{
${ }^{31}$ Para todo lo que viene a continuación remito a mi libro Las voces del Románico. Arte y epigrafía en San Quirce de Burgos, Murcia, Nausícaa, 2008, donde se hallarán debidamente argumentadas y ampliadas las ideas magramente expuestas en estas líneas.

${ }^{32}$ La narración discurre de izquierda a derecha con la creación de Adán y Eva (1a-2a), el pecado original (3a), la expulsión del Paraíso (4a-5a), la 'creación' de Abel (6a), su ofrenda y la de su hermano (7a-8a), el fratricidio (9a-10a) y la reprimenda de Dios a Caín (11a). Transcribo todas las inscripciones al pie de la fig. 3 .

${ }^{33}$ Cf. M. Zink, La prédication en langue romane avant 1300, Paris, Honoré Champion, 1976, pp. 289-290.
} 
A vueltas con la notatio. Frente al latín bíblico, litúrgico, libresco que dicta la historia pecaminosa, pero al fin y al cabo sagrada, de los primeros padres, los terrenales vitia de las tabicas se expresan en un "latin romanisé, déformé par la langue parlée, enrichi de mots vulgaires", en la precisa caracterización estilística de François Besson ${ }^{34}$. A diferencia de la matraca de Sisinio, los rótulos -ora elocutivos ora designativos- de las metopas burgalesas no son la concreción rotunda de una lengua, sino más bien una modalidad o realización lingüística, una forma de hablar. Si real o ficticia es lo de menos. Si sermo vulgaris a rajatabla, corruptum latinum, texto monolingüe o bilingüe, también. Averiguarlo es tarea de historiadores y filólogos. Lo que el artista y su mentor pretendían era recrear un habla de baja estopa que San Pablo habría calificado de «aut turpitudo, aut stultiloquium, aut scurrilitas» (Ef. 5,4$)$ y que los coetáneos litterati de la portada tildarían con sorna de sermo rusticus, esto es, «rusticanus et quodammodo bestialis» ${ }^{35}$, a tenor de su dominio romance y obscenidad léxica. Y lo que esperaban es que la vis comica de su doble vulgaridad (vulgaridades expresadas en una jerga vulgar o vulgarizada) tuviese en los espectadores un efecto inmediato a nivel expresivo, aunque escurridizo y equívoco en el semántico. De ahí la lúdica polisemia, más aparente que real, de la primera y última metopas $(1 \mathrm{~b}, 10 \mathrm{~b})$ : IO CACO es 'yo cago', pero también 'yo malo' («Quodque malum caco sit hoc cachesia probat», explica Eberhard von Bethune) ${ }^{36}$ y quizá 'yo Caco', en alusión al monstruoso «semihomine» de la fábula virgiliana («Verbum turpe caco, facies turpissima Caco», dice el saladísimo verso de Serlo de Wilton) ${ }^{37}$; y MALA CAGO significa 'manzanas cago' en la misma medida que 'males cago' y seguramente, para algunos hablantes, 'males qu'hago' (los males precisamente por los que nos guían el defecante y el gallo a lo largo de las siguientes tabicas), aunque en su improvisada vocalización más de un coetáneo habría espetado un entonado 'imala! cagó' 38 .

\footnotetext{
${ }^{34}$ «"À armes égales": Une représentation de la violence en France et en Espagne au XII siècle», Gesta, 26, 1987, pp. 113-126 (p. 123).

${ }^{35}$ Filipo de Harveng, Epistulae, XVI, ed. J.-P. Migne, Patrologia Latina (en adelante, PL), CCIII, col. 149.

${ }^{36}$ Graecismus, VIII, 60, ed. J. Wrobel (1887), reed. Hildesheim-Zürich-New York, Georg Olms Verlag, 1987, p. 30.

${ }^{37}$ P. Mastandrea y L. Tesarolo (eds.), Poetria Nova. Latin Medieval Poetry (650-1250 A.D.), CDROM, Firenze, Sismel, 2001, Appendices 2B, 1, v. 48.

${ }^{38}$ Para asimilar 'cago' a 'qu'hago' hay que suponer la pérdida temprana de la $f$-, algo que en Burgos ya se detecta en documentos de los siglos x y XI copiados en el XII. Cf. R. Menéndez Pidal, Orígenes del español, Madrid, $1956^{4}$, § 4.2, pp. 209-212, y R. Penny, «Labiodental /f/, Aspiration and /h/-Dropping in Spanish: the Evolving Phonemic Values of the Graphs $f$ and $h »$, en D. Hook y B. Taylor (eds.), Culture in Medieval Spain: Historical and Literary Essays presented to L. P. Harvey, London, King's College, pp. 157-182 (p. 158).
} 


\section{Daniel Rico CAmps}

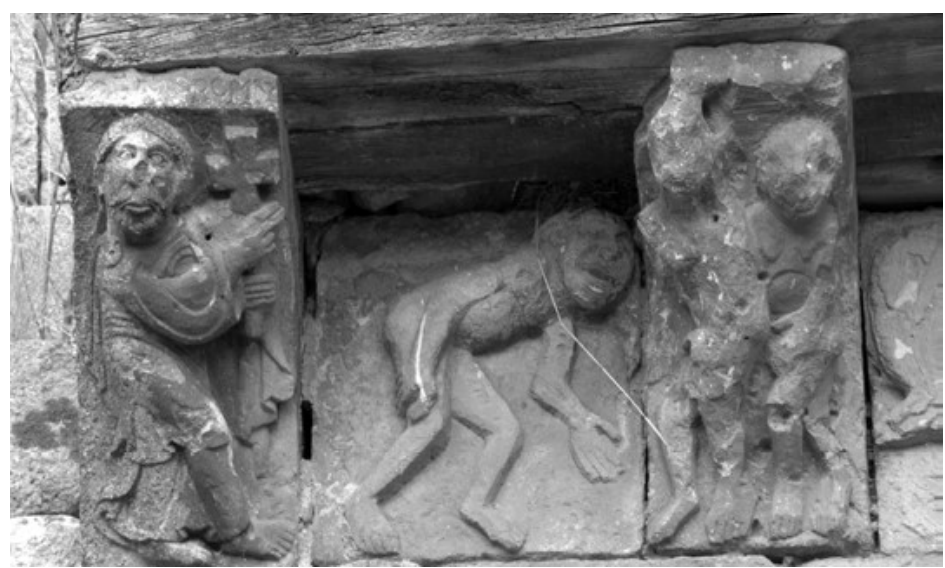

Fig. 4: Los Ausines (Burgos), iglesia de San Quirce,

cornisa de la portada occidental, labras 1a-1b-2a (foto: archivo del autor).

Del mismo modo que la última pareja de metopas (9b-10b) repite en orden inverso las figuras del gallo y el defecante del dueto inicial (1b-2b), a modo de figurativo quiasmo [fig. 3], las dos inscripciones de los extremos reverberan entre sí a manera de retruécano, jugando con la doble homonimia de mala y caco y con la sinonimia y metonimia que sus respectivos sentidos implican. Si en San Clemente teníamos «descoordinación», en San Quirce observamos desdoblamiento, inversión, ambigüedad, deformación ${ }^{39}$. Porque el pecado es exactamente eso: la radical alteración de la rectitudine original, aversio a Deo y conversio ad creaturam, que es lo que expresa cabalmente el hombre caído que da la 'espalda' a Dios y al orden primigenio en 1b para seguir el camino que le señala el lujurioso GALLO en $2 b$, echando por tierra (con las posaderas y con la mano izquierda) la divina benedictio - y nominatio- de ADAM y EVA en 1a-2a y abriendo así la vía de la maldición y de la mala dicción [fig. 4]. El pecado es concupiscentia en el sentido agustiniano: la revuelta del cuerpo contra el alma, de la sensualitas contra la ratio, de las facultades inferiores contra las facultades superiores, «factum vel dictum vel concupitum aliquid contra aeternam legem $»^{40}$. Los chillidos romanos de Sisinio podían leerse indistintamente de izquierda a la derecha o de derecha a izquierda por-

\footnotetext{
${ }^{39}$ Además de un contraste gráfico entre las inscripciones bíblicas de los canecillos, homogéneamente regladas en la franja superior de cada pieza, y las profanas de las metopas, dispuestas a capricho, unas veces en sentido horizontal y otras en el vertical o en una combinación de ambos, y a la izquierda, a la derecha, arriba o abajo de la figuración.

${ }^{40}$ San Agustín, Contra Faustum Manichaeum, XXII, 27 (ed. PL, XLII, col. 418). Cf. J. Delumeau, Le péché et la peur. La culpabilisation en Occident (XIIT-XVIII siècles), Paris, Fayart, 1983, espec. p. 214; O. Lottin, «Les théories du péché originel au XII ${ }^{\mathrm{e}}$ siècle», Recherches de Théologie Ancienne et Médiévale, 11 (1939), pp. 17-32 (pp. 21-22); y É. Gilson, Introduction a l'étude de Saint Augustin (1929), Paris, J. Vrin, 1969, p. 196.
} 
que la transgresión es desorden y corrupción, también del ars gramatica. El defecante burgalés igual está a la cola (en 1b) que a la cabeza (en 10b) de la massa damnata de las metopas, delante o detrás del lujurioso gallo $(2 \mathrm{~b}, 9 \mathrm{~b})$, y lo mismo dice 'yo malo' que 'yo cago', 'manzanas cago' que 'males cagó', porque el pecado es pura contrariedad y trágica contra-dicción ${ }^{41}$.

En San Quirce, la vulgarización del sagrado latín es al oído lo que la evacuación del fruto prohibido a la vista. En la metopa de partida, el latín degenera en romance (de mala a cago) en el mismo proceso en que las manzanas (el drama bíblico de los canecillos) se descomponen en muerte y residuo (la tragedia humana de las metopas), y por mediación del mismo órgano o conducto que las ha engullido. A pesar de su extrema grosería, la materia fecal no podía ser más pertinente para representar de una forma crasamente física e inmediata (al alcance de los feligreses más ignorantes) un concepto teológico caro a la Edad Media: el carácter original y universal del bocado de Adán; la corrupción (aquí indigestión) de la entera humanidad a raíz de un lapsus personal. Honorio de Autun lo resumió así: «omnis homo in natura est Adam, in persona filius Adam $\rangle^{42}$, que el alero se encarga de traducir con una burda metáfora fisiológica cuyo desdoblamiento lingüístico aprovecha la perspectiva parental con la que la Edad Media enfocó la propia historia de la lengua y la raza humanas, su multiplicación y degradación a partir de un tronco común ${ }^{43}$. Los defecantes del alero son hijos de Adán en su persona romance, pero verdaderos adanes en su natura latina; la dualidad de soportes dentro de una misma unidad arquitectónica es una forma ciertamente original de subrayar la propia dualidad, personal y humanal, del pecado original.

Es cosa bien sabida que la fuente principal de esta doctrina de larguísimo recorrido (durante y después de la Edad Media) ${ }^{44}$ es la Epístola a los Romanos de San Pablo, en particular el capítulo 7, uno de los textos que «ont exercé l'influence la plus déterminante sur nombre de positions dogmatiques parmi les plus importantes $\rangle^{45}$. Se trata del pasaje en que el apóstol ofrece un crudo diagnóstico de la inclinación al mal que domina en el ser humano a consecuencia del pecado de Adán y Eva, lo que él denomina la «ley

\footnotetext{
${ }^{41}$ No hace falta que recuerde la acepción gramatical, de San Isidoro (Etym. I, 34, 1) en adelante, de la palabra vitium, compartida por peccare (cf. F. Rico, «El "pecado" del "mester"», Primera cuarentena y tratado general de literatura, Barcelona, El Festín de Esopo, 1973, pp. 49-51).

${ }^{42}$ Elucidarium, II, 11 (ed. PL, CLXXII, col. 1142).

${ }^{43} \mathrm{Cf}$. H. Bloch, Étymologie et généalogie. Une anthropologie littéraire du Moyen Age français, Paris, Seuil, 1989, espec. pp. 56-58 y 79-80.

${ }^{44}$ Para una completa panorámica de su incidencia medieval, cf. A. Gaudel, «Péché originel», en Dictionnaire de théologie catholique, 12, Paris, Letouzey et Ané, 1933, cols. 275-606 (espec. pp. 371-402), y Lottin, art. cit., 11 (1939), pp. 17-32; 12 (1940), pp. 78-103; y 13 (1941), pp. 236-274.

${ }^{45}$ S. Lyonnet, Études sur l'Épître aux Romans, Roma, Pontificio Istituto Biblico, 1989, p. 203. 
del pecado y de la muerte», para cuya exposición adopta, del versículo 7 al 25 , la forma autobiográfica, truncando inesperada y provisionalmente el tono narrativo del resto del texto: «ego autem mortuus sum... carnalis sum...» (Rom. 7, 10 y 14), hasta concluir el periodo con la influyente exclamación «Infelix ego homo, quis me liberabit de corpore mortis huius?» (Rom. 7, 24). La exégesis más autorizada ve en el empleo de la primera persona «una figura estilística (...) para dramatizar de una forma íntima y personal la experiencia común» a todos los mortales ${ }^{46}$. Este "homme, type de l'humanité (bien propre à être désigné par $\dot{\varepsilon} g \omega ́){ }^{» 47}$, fue fuente de inspiración, directa o indirecta, de numerosos sujetos pecadores de la literatura medieval $-v$. gr., el "yo, como só omne como otro, pecador" del Libro de buen amor (c. 76)-, y está claro que con idéntico enfoque hay que entender el yo colectivo que da voz a los «servi peccati» (Rom. 7, 14) de San Quirce a través de sus tres únicos epígrafes elocutivos, no en vano situados al inicio, en medio y al final del plano de las metopas. 'Yo hombre', vienen a decir las metopas, ergo 'pecador', por cuanto quien obra en la naturaleza humana, aclaran los canecillos, es la falta original. El yo de $5 \mathrm{~b}$-(des)calificado por la imagen como «pene prominente ultra modum animalium» (que diría la Historia Augusta, X, 1)- se siente ('yo cago') y se sabe ('yo malo') siervo del pecado original ('manzanas cago').

El uso de la primera persona en la obra burgalesa tiene un cierto paralelo en el lamento de Adán inscrito en la fachada de San Zeno de Verona, pero en el arte románico es sumamente extraño "to find sculpted figures who speak in the first person" ${ }^{48}$. Sin descartar que en San Quirce se introdujese como paródica inversión del evangélico "Ego sum ostium" de Jn. 10, 9, tan socorrido en cambio en la epigrafía arquitectónica coetánea, a mí me da la impresión de que la despertó la propia ruminatio del texto paulino. No sólo porque la teología esbozada por el apóstol alimenta las grandes ideas de la cornisa, sino porque su inscripción más chispeante -MALA CAGO- parece haber salido de una lectura mot à mot de la que fue la oración más carismática y comentada de la Epistola: «non enim quod volo bonum, hoc facio: sed quod nolo malum, hoc ago» (Rom. 7, 19). Sí, lo hemos oído bien: «malum, hoc'ago». El cacofatón, «dictio turpe sonans»-en la concisa definición de Alejandro

${ }^{46}$ J. Fitzmyer, «Carta a los Romanos», Comentario Bíblico «San Jerónimo», IV, Madrid, Ediciones Cristiandad, 1972, p. 155. Una presentación extensa del tema, en J.-M. Cambier, «Le "moi" dans Rom. 7», en L. De Lorenzi (ed.), The Law of the Spirit in Rom. 7 and 8, Roma, St Paul's Abbey, 1976, pp. 13-72.

${ }^{47}$ S. Lyonnet, «Notes au commentaire du Père Huby», en J. Huby, Saint Paul. Épitre aux Romans, ed. rev. S. Lyonnet, Paris, Beauchesne, 1957, p. 603.

${ }^{48}$ C. B. Kendall, The Allegory of the Church. Romanesque Portals and their Verse Inscriptions, Toronto-Buffalo-London, University of Toronto Press, 1998, p. 86, a propósito del epígrafe veronés. 
de Villadei ${ }^{49}$ - o «mal son» - explica Nebrija- que se produce «cuando del fin de una palabra i del comienço de otra se haze alguna fea sentencia $»^{50}$, no se resiste a nadie que tenga el castellano por lengua materna, en especial si la lectura se hace en voz alta o sotto voce: k'ago, efectivamente, suena con grotesca rotundidad y en el preciso momento en que, lo que se lee y se entiende en latín ('el mal que no quiero, eso hago'), se cumple o realiza por dicción y sobreinterpretación en lengua romance (soltar o pensar una obscenidad). $\mathrm{Si}$, además, para cierta comunidad de hablantes (ut supra, n. 38 ) «hoc ago» podía enredarse igualmente con 'qu'hago', como en "aquel cantar en que burlaron los nuestros antiguos ¿qué hazes Pedro?, etc." evocado por Nebrija $\mathrm{y}$ en el que debemos suponer réplicas del tipo ‘¿qu'hago?' o gracejos como el de Correas (“¿Qué queréis qu'haga? -Un día qu'haga sol y amanezca de espacio") $)^{51}$, es ya harina de otro costal. Lo que aquí importa recalcar es la confusión fonética entre "hoc ago" y 'cago', y descubrir con ella hasta que punto, en la inestable realidad lingüística del siglo XII, un conflicto moral (ese querer hacer el bien y no poder hacer más que el mal del hombre paulino) podía vivirse (esto es, decirse y oírse) como un conflicto lingüístico ${ }^{52}$. La interferencia del dicho vulgar y mundano sobre el escrito latino y sagrado es inevitable $\mathrm{y}$, en aquellos tiempos de eclesiástica diglosia, tuvo que parecer sumamente reveladora, por cuanto la deformación de la palabra apostólica por injerencia de la sucia lengua románica no hacía sino confirmar la pecaminosidad del sermo maternus. A cualquier clérigo dotado de cierto sentido del humor, le bastaba volver un instante sobre el «malum» de la Epistola y masticar su doble y convergente significado latino para experimentar el «mal son» como ahogo e indigestión y ver desbocarse la imaginación. Así es como creo que nació un programa audiovisual que, de manera harto significativa, empieza y acaba con un paralelismo figurativo -el ya aludido reflejo de $1 \mathrm{~b} / 2 \mathrm{~b}$ en 9b/10b- tan quiásmico como el célebre aforismo de San Pablo, «volo bonum... nolo malum».

${ }^{49}$ Doctrinale, v. 2380, ed. y trad. de Marco A. Gutiérrez Galindo, El Doctrinal. Una gramática latina del Renacimiento del siglo XII, Madrid, Akal, 1993, pp. 158 y 187.

${ }^{50}$ Gramática castellana (1496), IV, 7, ed. P. Galindo Romeo y L. Ortiz Muñoz, Madrid, CSIC, 1946, I, p. 97.

${ }^{51}$ Cf. J. Casas Rigall, «Cinco conceptos retóricos oscuros en las gramáticas de Antonio de Nebrija», en Homenaje a Benito Varela Jácome, ed. A. Abuín González, J. Casas Rigall y J. M. González Herrán, Universidad de Santiago de Compostela, 2001, pp. 121-140 (p. 125).

${ }^{52}$ La denuncia del cacofatón o «cacenphaton» y de otros vicia análogos como la aiscrología recorrió sin solución de continuidad la Antigüedad y la Edad Media, según ha puesto de manifiesto Jan M. Ziolkowski, «The Latin Grammatical and Rethorical Tradition», en J. Ziolkowski (ed.), Obscenity. Social Control \& Artistic Creation in the European Middle Ages, Leiden-Boston-Köln, Brill, 1998, pp. 41-59, espec. pp. 49-55. 


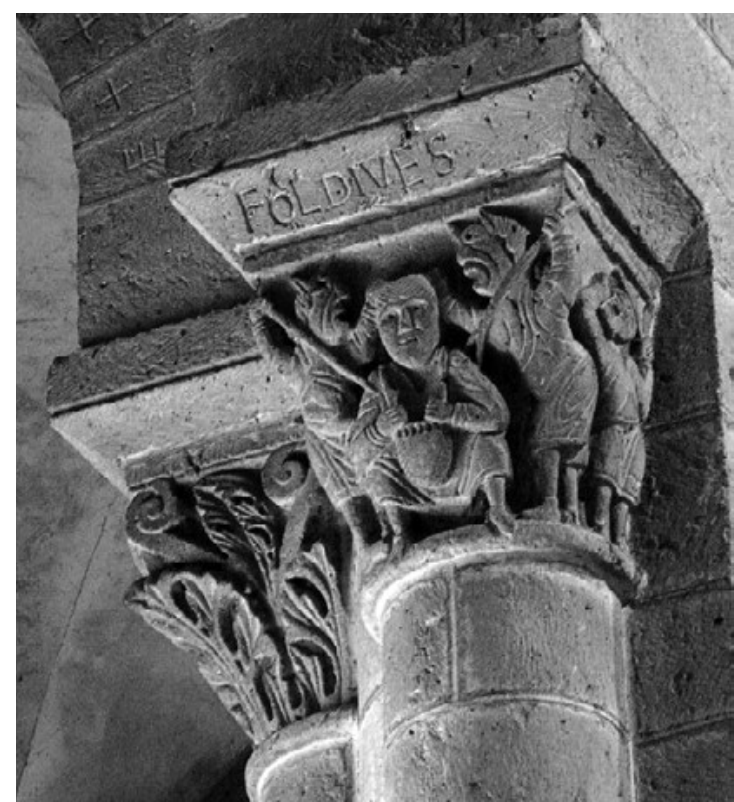

Fig. 5: Puy-de-Dôme (Auvergne), iglesia de Notre-Dame d'Orcival, capitel del interior (foto: archivo del autor).
Tanto en San Quirce como en San Clemente lo que se pone en escena no es el sermo vulgaris en bloque, sino tan sólo su registro más bajo y jergal. Quiere esto decir que en la elección de la lengua vulgar como forma auditiva de la maldad del ser humano no intervino tan sólo el prejuicio moral o doctrinal que la Iglesia hacía recaer sobre ella, sino también -o sobre todo-el hecho de que dicha lengua se prestaba a ello mucho mejor que el sagrado latín. Frente a la inmutabilidad y regularidad de la lengua escrita, el romance ofrecía inestabilidad e im-

perfección, una deformidad orgánica que decía de maravilla con la noción teológica del pecado como transgresión -volviendo a San Agustín- de la ley eterna. Pero sobre todo ofrecía vivacidad y realismo, y por lo tanto estaba bastante mejor preparado que el anticuado y artificial latín para expresar el vicio y lo indecible. Obsérvese que lo que unifica las inscripciones de Roma y Burgos no es la lengua propiamente dicha, sino su lenguaje obsceno, ultrajante, brusco, hostil: fili de le pute..., mala cago... yo... Como ha señalado Jan M. Ziolkowski, "obscenity was one of the registers toward which the vernacular writers could turn in order to establish the validity of writing in the vernacu$|a r\rangle^{53}$. Y lo mismo cabe decir de las dos dimensiones del lenguaje y la experiencia que a mi juicio constituyen los rasgos distintivos del vulgar reflejado tanto en San Quirce y San Clemente como en el resto de las inscripciones del tercer grupo: la violencia y el humor. En los siglos XI y XII, la broma, el taco o la indecencia se decían y entendían más y mejor en romance que en latín, sobre todo en contextos abiertos al gran público y que, a diferencia del altar de Grandmont, estaban destinados a excitar lo que San Bernardo llamaba «carnalis populi devotionem». No hay modo más inmediato de comprobarlo que tomando la inscripción bilingüe del capitel de Orcival evocado al principio de

\footnotetext{
${ }^{53}$ «The Obscenities of Old Women. Vetularity and Vernacularity», en Ziolkowski (ed.), ob. cit., pp. 73-89 (p. 75).
} 
estas páginas [fig. 5], FOL DIVES, y sustituir el término vulgar por cualquiera de sus correspondientes latinos más o menos cercanos: insipiens, fatuus, stultus... dives. No es lo mismo. No lo es hoy y tampoco lo fue en la Edad Media desde el momento mismo en que la lengua materna dejó de ser el latín. Llamar al rico de la parábola evangélica fol en vez de stultus era como apostrofarlo burro! en lugar de asine!, es decir, un agravio más degradante y denigrante, más convincente y hasta más operativo, en la medida en que vejar al avaro equivalía tanto a castigarlo y vengarse de él como a exorcizarlo. La eficacia de la lengua vulgar era en este punto muy superior a la latina, en el plano comunicativo igual que en el puramente artístico o expresivo. La Iglesia se recreaba, sin duda, en la miseria moral del romance, pero, a conciencia o sin ella, abría al tiempo una pequeña puerta al reconocimiento de la eloquentia vulgaris, por primera vez en formato epigráfico.

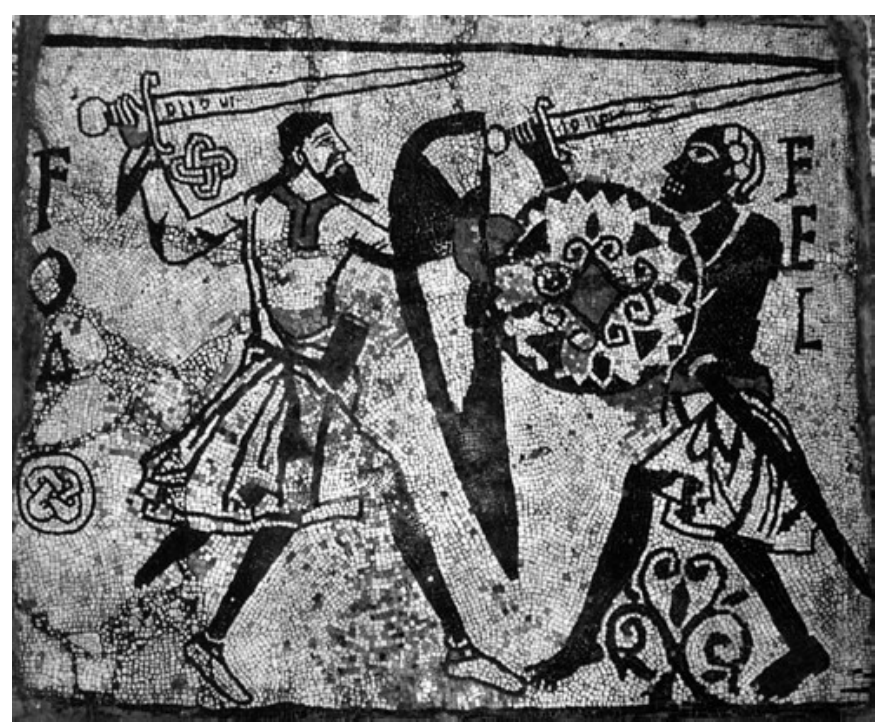

Fig. 6: Vercelli, catedral de Santa Maria Maggiore, mosaico pavimental (Museo Camillo Leone, Vercelli) (foto: archivo del autor).

La hostilidad verbal como recurso estilístico para remachar un vicio o costumbre reprobable es exactamente lo que volvemos a encontrar en los mosaicos pavimentales de la catedral de Vercelli [5] y la vecina ex-colegiata de Casale Monferrato [7]. De ambos conjuntos se conservan dos paneles coetáneos $\mathrm{y}$ harto parecidos en los que se escenifica un combate entre dos guerreros que se cruzan espadazos al par que epigráficas amenazas. En el enfrentamiento de Vercelli [fig. 6] entre un blanco y barbudo cristiano y un negro y dentudo sarraceno, el primero le larga FOL-ya es coincidencia-al segundo mientras éste 
arremete a su vez con un airado FEL ('bellaco, felón'). En la escena de Casale, donde los contrincantes son prácticamente idénticos y los dos cristianos, el de la izquierda se lanza sobre el de la derecha con un desafiante T'Ò SCANÀ, «un'apostrofe classicamente intimidatoria, del tipo 'sei un uomo morto', che Stella preferisce parafrasare con 'ti scannerò'» (p. 9), 'te ahogaré', a lo que el otro debió responder con alguna expresión similar por desagracia desaparecida. Todas estas inscripciones tienen una función artística clara: llenar de actualidad los combates verbalizados, dotarlos de una tonalidad cotidiana y de una espontaneidad viva y contemporánea que empujase a los milites de carne y hueso coetáneos de ambas obras a reconocerse en sus homólogos artísticos. Pero ¿con qué objetivo moral? Si no tuviésemos las inscripciones, estaría justificado interpretar las dos escenas en clave positiva: la de Casale, por ejemplo, como una alegoría de la batalla espiritual a la manera de la conocida imagen marginal del Salterio de St. Albans, y la de Vercelli como invitación a la lucha contra el infiel e incluso como encomio o encarecimiento de la segunda cruzada $^{54}$. Pero los letreros no dan lugar a dudas. Como señaló Angelo Coppo, su finalidad es mostrar «l'estrema volgarità dei duellanti, attraverso la crudeza del loro linguaggio ${ }^{55}$, lo que convierte ambas escenas en una condena de la violencia contemporánea; de cualquier tipo de violencia armada, me permito precisar-como en las metopas $3 \mathrm{~b}$ y $4 \mathrm{~b}$ de San Quirce-, y no de la del duelo judicial en particular, como sugiere Coppo y rebate, con razón, Petrucci (p. 87). Cierto que las palabras ultrajantes entre moros y cristianos aparecen una y otra vez en la literatura épica como realistas gritos de guerra ${ }^{56}$, pero no es baladí recordar que aquí no estamos hablando de la Chanson de Roland sino de obras eclesiásticas situadas en el umbral del coro de sus respectivas iglesias. Vercelli nos ofrece además un argumento suplementario, ya que la imagen del combate se localizaba originalmente al lado de un panel en el que estaban retratados los dos artífices del mosaico, con sus nombres y la fecha de la obra en latín: imagen y palabras celebrativas del buen hacer frente al impetuoso y malsonante oficio de las armas. La relación semántica entre ambas escenas no sólo la avalan su emparejamiento y contraposición temática y lingüística, sino también el revelador hecho de ser las dos únicas imágenes del conjunto musivo consagradas a hechos contemporáneos.

\footnotetext{
${ }^{54} \mathrm{Vid} .$, recientemente, G. Ligato, L'ordalia della fede: il mito della crociata nel frammento di mosaico pavimentale recuperato dalla basilica di S. Maria Maggiore a Vercelli, Spoleto, Fondazione Centro italiano di studi sull'alto Medioevo, 2011.

${ }^{55}$ «Tre antiche iscrizioni volgari su frammenti musivi pavimentali di Casale e Vercelli», Atti della Pontificia Accademia Romana di Archeologia. Rendiconti, 38 (1967), pp. 237-266 (p. 249).

${ }^{56} \mathrm{Cf}$., a modo ilustrativo, N. Gonthier, «Sanglant Coupaul!» «Orde Ribaude!». Les injuries au Moyen Âge, Rennes, Presses Universitaires de Rennes, 2007, p. 14.
} 


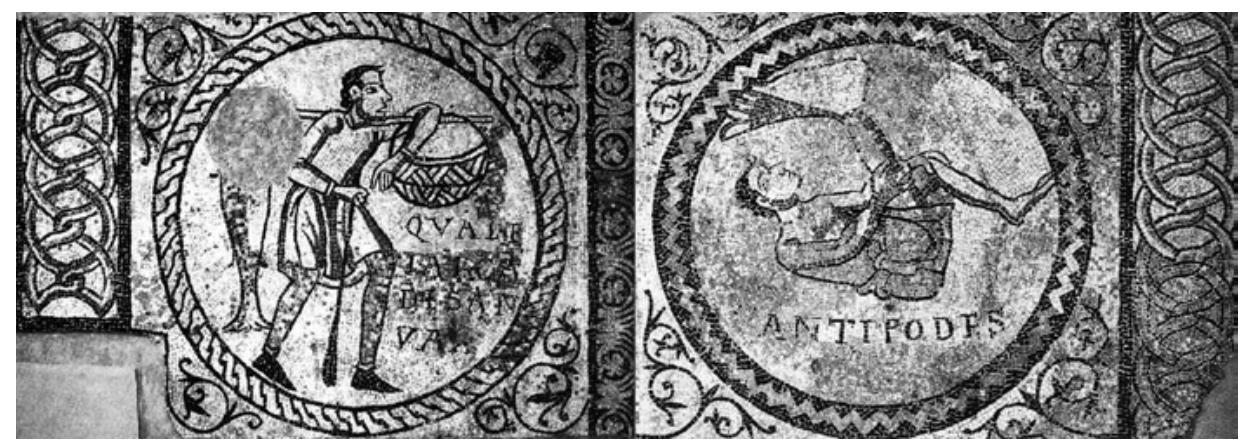

Fig. 7: Casale Monferrato (Alessandria), colegiata (ahora catedral) de Sant'Evasio. mosaico pavimental (foto: archivo del autor).

Del pavimento de Casale ha sobrevivido otro texto vernáculo (único caso, junto a la lucha, de un ambicioso ciclo en el que el resto de las inscripciones -hasta ocho- se redactaron en latín) cuyo significado último está más abierto a la discusión [fig. 7]. Vemos la imagen de un pescador que camina hacia algún lugar ayudándose de un remo a modo de bastón mientras carga sobre el hombro izquierdo una pértiga de la que cuelgan un enorme pez en el extremo posterior y una canasta vacía en el anterior. La inscripción corre por delante suyo y encarna la pregunta que el hombre dirige -entreabriendo la boca y extendiendo el índice de la mano izquierda- a "circostanti fuori campo» (p. 91): QUAL È L'ARCA DE SAN VAX?, es decir, ‘¿Cuál es el arca de San Evasio?'. El propio padre Coppo ha demostrado que el «arca de san Vax» no era otra cosa que el archa de la obra -documentada con dicho término en 1158- de la colegiata de Sant'Evasio, que por aquel entonces gozaba del derecho sobre el diezmo del pescado ${ }^{57}$. Salta a la vista, por consiguiente, que estamos ante una imagen exhortativa destinada a recordarles a los fieles de Casale sus deberes económicos para con la iglesia. Lo que no me queda tan claro es que el pescador se apresure, como sostiene Petrucci, «ad assolvere con larghezza al dovere della decima» (p. 9). Tal posibilidad dice mal con el aire jocoso que parece transpirar toda la escena, tanto por el carácter interrogativo de la inscripción como por la comicidad que cabe atribuir a la propia elección de la lengua vulgar, aunque sólo sea por analogía y cercanía con el cuadro de la lucha que ya hemos comentado. Me pregunto si la imagen aparentemente ejemplar del pescador no será más bien la viva caricatura del granuja impostor, que trata de evitar sus obligaciones decimales con el ardid de hacerse el distraído o el desorientado. La interpretación podrá parecer forzada, pero no hay que olvidar que, en origen, el panel estaba pegado a otro

${ }^{57}$ Art. cit., pp. 242-324. 
con la personificación de los ANTIPODES y que hacia ella es hacia donde en el fondo se dirige (por lo menos visualmente) el despistado marino [fig. 8]. Es como si se nos quisiese irónicamente decir que su destino real es el diametralmente opuesto al arca de san Vax, y quizá también que el suyo es un paso que pisa al revés del resto de los mortales o aplicados contribuyentes a las arcas de la Iglesia. Quién sabe si el cepillo de la ofrendas de Sant'Evasio estaba situado precisamente a espaldas del pescador y si la contraposición entre el gigantesco pescado y el canasto vacío que el hombre transporta tuvo un preciso significado iconográfico.

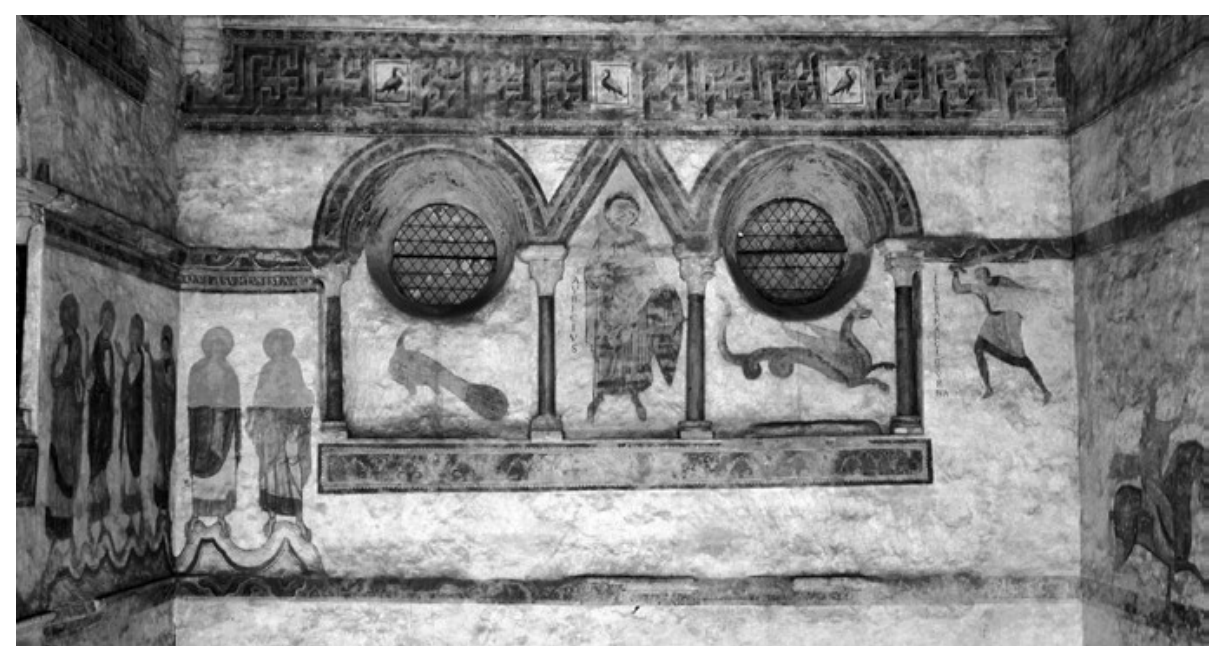

Fig. 8: Poitiers (Vienne), baptisterio de Saint-Jean, pintura mural (cliché: CESCM - Jean-Pierre Brouard).

Aún mayores son las dificultades interpretativas que plantea el último ejemplo de este grupo de inscripciones a las que ya hace un buen rato que deberíamos haber rotulado como 'expresivas con función pastoral'. Volvemos a Francia para entrar ahora en el celebrado baptisterio de Saint-Jean de Poitiers [6], a la sazón iglesia parroquial, y contemplar la parte más elevada de su pared meridional [Fig. 8]. Allí vemos un mural organizado a modo de tríptico con la figura grandiosa de San Mauricio en la calle central, armado de lanza y escudo y con su nombre bien resaltado en latín (MAURICIUS), flanqueada en las laterales por un pavo, que vuelve la cabeza para mirar al santo (señalando así su inmortalidad), y por un dragón alado que se aleja de su presencia para enfrentarse con un hombre, espada en alto y vestido con túnica corta, situado en el extremo derecho, fuera ya del delimitado campo arquitectónico en el que se inscribe el terceto. El texto que nos interesa separa al dragón del guerrero y en su día se extendía horizontalmente en forma de $\mathrm{L}$, ofreciéndole al soldado un 
terrenal -y vernáculo- punto de apoyo [Fig. 9]. A mediados del siglo XIX, Alphonse de Longuemar ${ }^{58}$ llegó a leer lo siguiente: E I L CRIA MARCI ET URNALES LADA... EFERT, que los editores modernos han corregido de esta forma: CIL CRIA MARCI E TURNA [...], deteniéndose justo ahí porque el resto de la inscripción («leslada... efert» o, mejor, «leslada... e fert», como sospecha Favreau al reconocer en la última palabra el verbo ferir, 'herir, golpear') se ha perdido irremediablemente. De momento, la única traducción que se ha propuesto parece la más literal: 'Éste imploró misericordia y huyó ${ }^{59}$. Pero plantea el incómodo problema de que su contenido casa francamente mal con el aparente significado de la imagen. Pues ¿quién es el que pide misericordia y pone pies en polvo-

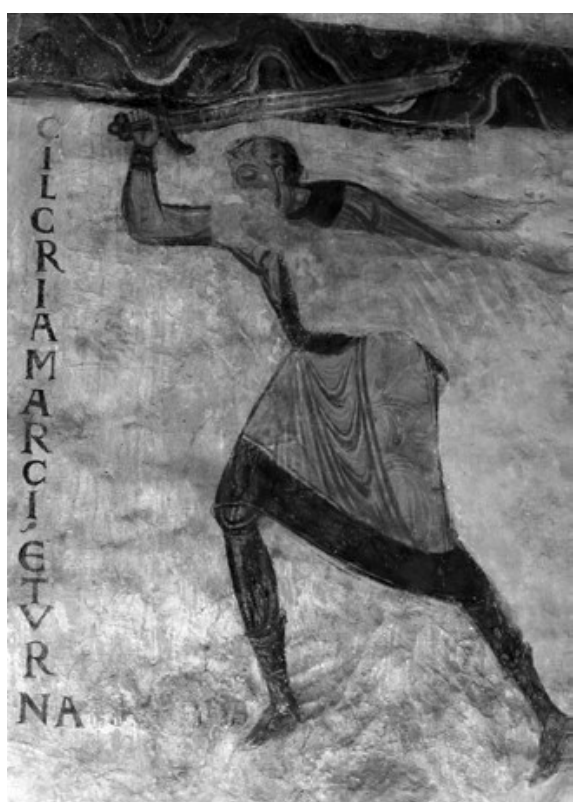

Fig. 9: Poitiers (Vienne), baptisterio de Saint-Jean, pintura mural, detalle (cliché: CESCM - Jean-Pierre Brouard).

rosa? Desde luego no el envalentonado guerrero, pero tampoco el amenazador dragón, si nos atenemos a la literalidad de la imagen y suponemos, como parece lógico, que el letrero está glosando su visible encontronazo ${ }^{60}$. El embrollo es tal, que sólo se me ocurren dos maneras de desenredarlo. O presumimos que el

${ }^{58}$ «Épigraphie du Haut Poitou», Mémoires de la Société des Antiquaires de l'Ouest, 28 (1863), pp. 43-398 (p. 210).

${ }^{59} \mathrm{La}$ expresión crier merci es común en francés antiguo y, obviamente, no es difícil verla asociada a un verbo de movimiento como tourner (v. gr., «lors se tourna vers lui et li cria merci», en Le roman de Tristan en prose, dir. P. Ménard, VIII, Genève, Droz, 1995, p. 182). Frank y Hartmann han supuesto que la parte legible del texto sería la «citation d'un vers d'une oeuvre littéraire» (ob. cit., I, p. 71), aunque sin argüir razón alguna. Más datos aporta E. Ingrand-Varenne al observar que la frase está ritmada por asonancias en $i$ y en $a$ y que tiene las ocho sílabas necesarias para conformar el octosílabo que pediría su presunto contexto poético (Langues de bois, de pierre et de verre. Histoire du langage épigraphique et de son passage du latin au français (Ouest de la France, XII -XIVe siècles), tesis doctoral, Université de Poitiers, 2013, p. 376).

${ }^{60}$ No se ha planteado la posible transitividad de TURNA, que permitiría interpretar LESLADA... E FERT como la desafortunada lectura de L'ES $<\mathrm{P}>\mathrm{ADA}$... E FER $<\mathrm{I}>$ y leer, en consecuencia, «turna l'espada... e feri...», 'volvió la espada... y golpeó'. En principio, que espada (o espasa) sea una forma occitana no constituye ningún obstáculo, por cuanto el Poitou pertenecía en el siglo XII «à un zone linguistique mouvante, entre langue d'oïl et langue d'oc» (Ingrand-Varenne, ob. cit., p. 445). El problema radica en que esta lectura tampoco soluciona la contradicción entre la beligerancia de la imagen y la súplica con la que arranca el texto; al contrario, la agrava, a no ser que crier merci pueda entenderse como 'imploró la ayuda de Dios', cosa de la que no tengo ninguna constancia documental. 
texto se refiere irónicamente al futuro desenlace del combate, anticipando con palabras -a pesar del pretérito indefinido- lo que la imagen venía a negar con figuras, es decir, la escabullida del guerrero. O suponemos que el texto glosa efectivamente la espantada del dragón -por mucho que nos cueste imaginarlo clamando compasión-, sea a causa del nervio y la valentía del guerrero (variante de lo más improbable), sea por amilanarse ante la presentia y potentia del legendario comandante de la Legión Tebana. En este último caso, la inscripción estaría introduciendo en medio del inminente enfrentamiento una suerte de flashback que vendría a contarnos que 'Éste [el dragón] imploró [el] perdón [del santo] y huyó...' para toparse repentinamente con el laico, que entraría en escena justo en el momento en que la última sílaba de turna toma la horizontal de la L, volviendo -literalmente- la inscripción hacia territorio humano.

Confieso que ninguna de las dos interpretaciones me convence demasiado

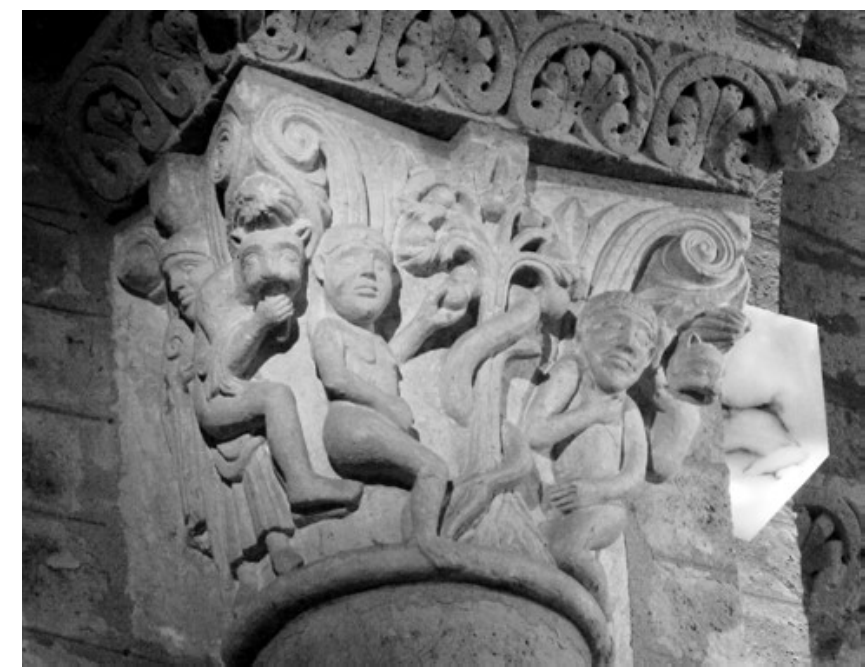

Fig. 10: Frómista (Palencia), iglesia de San Martín, capitel del interior (foto: archivo del autor).

(la primera mucho menos que la segunda), a pesar de que las dos tiñen la escena de esa comicidad que me parece adivinar en el resto de la inscripciones del mismo grupo y que explicaría bien la utilización de la lengua vulgar. Tanto en uno como en otro caso, la inferioridad moral asociada al romance ofrecería el tono adecuado para expresar una forma de debilidad: la cobardía del guerrero, en el primero, y la insensatez del monstruo, en el segundo; o quizá el acorralamiento del dragón (por escapar de una amenaza para toparse con otra a la vuelta de la esquina) al tiempo que la temeridad del propio guerrero, de la que también serían expresión su excitación y escasa estatura en contraste con el aplomo y envergadura de San Mauricio. Precisamente, la naturaleza laica 
y la posición marginal del soldado, que no sólo está situado fuera del campo iconográfico del santo, el pavo y el dragón, sino que contrasta en todo -tamaño, porte, ubicación-con los apóstoles y caballeros representados en los paños de muro contiguos, lo identifican en principio como una figura 'profana', del estilo de las muchas que pueblan los bordes y rincones de los grandes programas escultóricos coetáneos y que, desde sus espacios limítrofes -canecillos, dovelas, marcos, enjutas, capiteles-, introducen una nota de humor (a menudo grotesco y hasta lingual, como en mi fig. 10) destinada la mayoría de las veces a realzar ex contrario la gravedad o verdad de las historias sagradas representadas en los majestuosos espacios centrales. Lo interesante del asunto es que también el vulgar de la inscripción introduciría en nuestro caso un cambio similar de tonalidad, un registro 'profano' o, en rigor, humano -tanto por hablar la lengua materna como por referirla a una derrota, la única representada en todo el ciclo pictórico- en un contexto epigráfico del que todavía se conservan cuatro inscripciones más todas ellas escritas en solemne latín ${ }^{61}$.

Si asumimos lo que parece más razonable, que el texto se refiere a la huida del dragón, lo más factible es también suponer que la inscripción y el guerrero son en realidad la misma cosa: una rúbrica verbal y visual, romance y laica, vernácula y secular que introduce una nota narrativa en un tríptico o icono concebido a modo de teofanía. El guerrero y su texto (suyo, no tanto porque sea él quien lo verbaliza como por pertenecer a su mismo mundo, terrenal y actual) se concibieron pues como una suerte de glosa marginal o manicule $e^{62}$ con la doble función de subrayar por contraste la sacralidad de San Mauricio -su latinidad y envergadura- y de enriquecer la visión de su majestuosa figura contándonos -a nosotros, hombres asimismo vulgares y contemporáneosun detalle casi anecdótico de su victoria sobre el mal. El guerrero y el texto que lo envuelve están fuera del tríptico de San Mauricio porque no participan de su realidad sagrada, sino de la nuestra. Son nuestros guías o cicerones, y por eso despiertan nuestra atención en romance (en un romance, si no cómico, al menos simpático y difícil de olvidar) y se entretienen en señalarnos la derrota del dragón y la sorpresa, vulnerabilidad o lo que fuere del valiente e iluso guerrero, en vez de relatarnos -en latín, obviamente- el martirio o las hazañas del comandante tebano.

Recibido: 06/04/2013

Aceptado: 11/05/2013

\footnotetext{
${ }^{61}$ Cf. CIFM, I, núms. 8-12, pp. 9-13.

${ }^{62}$ «[The] hand-with-pointing-finger symbol», en la terminología de William H. Sherman, «Toward a History of the Manicule», 2005, <http://www.livesandletters.ac.uk/papers/FOR_2005_04_001.pdf $>$.
} 
$\cos$

RESUMEN: En este ensayo se analizan las primeras inscripciones en lengua vulgar de la Europa románica. Se trata de un pequeño corpus de trece inscripciones o unidades epigráficas de los siglos XI y XII, once de las cuales fueron concebidas y realizadas en estrecha articulación con motivos o programas iconográficos. El autor trata de dilucidar la imagen (voluntaria o involuntaria) de la lengua romance que hay detrás de cada una de ellas, llegando a distinguir hasta tres niveles de uso de la lengua por parte de la Iglesia, a los que califica respectivamente de «neutro o utilitario», «expresivo sin función pastoral» $\mathrm{y}$ «expresivo con función pastoral». En conjunto, el debut epigráfico de las lenguas romances fue muy limitado, pero también muy creativo y experimental, en consonancia con el propio arte románico en cuyo marco se produjo.

ABSTRACT: This essay explores the first vernacular inscriptions in Romance Europe. These are a small corpus of thirteen inscriptions or epigraphic units from the Eleventh and Twelfth Centuries, of which eleven were designed and carried out in close connection with iconographic programs or motifs. The author tries to elucidate the conscious or unconscious image of the vernacular language that there is behind each of them, and he comes to distinguish three different levels of using the vernacular by the Church, which are respectively defined as «neutral or utilitarian», «expressive without pastoral function», and «expressive with pastoral function». On the whole, the epigraphic debut of the vernacular languages proved to be very limited, but it was also really creative and experimental, in line with the artistic framework in which it was produced, Romanesque art.

Palabras Clave: Epigrafía vulgar. Lenguas romances. Arte románico.

KeYwords: Vernacular epigraphy. Vernacular languages. Romanesque art. 